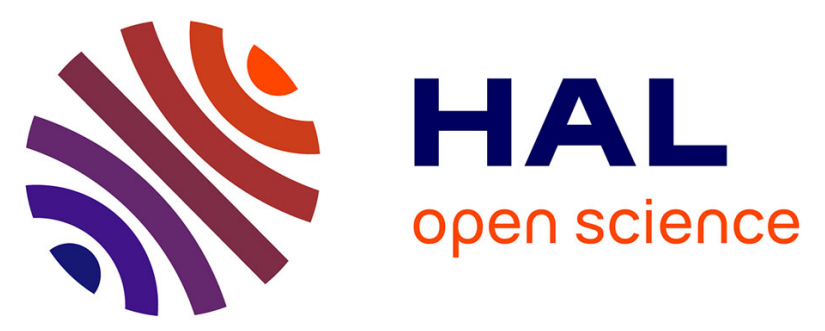

\title{
Digestive enzyme ratios are good indicators of hatchling yolk reserve and digestive gland maturation in early life stages of cuttlefish Sepia officinalis L.: application of these new tools in ecology and aquaculture
}

Georges Safi, Anne-Sophie Martinez, C. Le Pabic, E. Le Bihan, J. Robin, N. Kouéta

\section{To cite this version:}

Georges Safi, Anne-Sophie Martinez, C. Le Pabic, E. Le Bihan, J. Robin, et al.. Digestive enzyme ratios are good indicators of hatchling yolk reserve and digestive gland maturation in early life stages of cuttlefish Sepia officinalis L.: application of these new tools in ecology and aquaculture. Journal of Comparative Physiology B, 2018, 188 (1), pp.57-76. 10.1007/s00360-017-1115-4 . hal-01688312

\section{HAL Id: hal-01688312 \\ https://hal.sorbonne-universite.fr/hal-01688312}

Submitted on 19 Jan 2018

HAL is a multi-disciplinary open access archive for the deposit and dissemination of scientific research documents, whether they are published or not. The documents may come from teaching and research institutions in France or abroad, or from public or private research centers.
L'archive ouverte pluridisciplinaire HAL, est destinée au dépôt et à la diffusion de documents scientifiques de niveau recherche, publiés ou non, émanant des établissements d'enseignement et de recherche français ou étrangers, des laboratoires publics ou privés. 
Digestive enzyme ratios are good indicators of hatchling yolk reserve and digestive gland maturation in early-life stages of cuttlefish Sepia officinalis L.: application of these new tools in ecology and aquaculture.

Safi G. ${ }^{* 12}$, Martinez A.S. ${ }^{12}$, Le Pabic C. ${ }^{12}$, Le Bihan E. ${ }^{3}$, Robin, J.P. ${ }^{12}$, Koueta N. ${ }^{12}$

${ }^{1}$ Normandie Université, Université de Caen Normandie, UMR BOREA (Biology of Aquatic Organisms and Ecosystems, MNHN, UPMC, UCBN, CNRS-7208, IRD-207, UCN, UA), CS 14032, 14032 Caen cedex 05, France

${ }^{2}$ Centre de Recherches en Environnement Côtier, Université de Caen Normandie, 54 rue du Docteur Charcot, 14530 Luc-sur-Mer, France

${ }^{3}$ Société IVAMER, 32 rue Fragonard, 14220 Thury Harcourt, France

\section{*Corresponding author:}

Georges Safi: safigeorges@hotmail.fr

\section{$\underline{\text { Acknowledgments }}$}

This work was supported by European funding as part of the CRESH (Cephalopods Recruitment from English Channel Spawning Habitats) INTERREG IV-A project and by the regional funding of Basse-Normandie. This work was achieved in the CREC marine research station (for the rearing) and in BOREA laboratory (for biochemical and histological analysis). We would like to thank Mrs. Béatrice Adeline for her precious help in achieving the histological sections and Mrs. Laura Varin for her great job, during her internship, in processing histological slides for digestive vesicles counting, which is a very long and time-consuming work. We are grateful to Mrs. Céline Quint from the international language service of the University of Caen "Le Carré international" for professional English editing of the manuscript. Finally, we are thankful to reviewers for their comments and suggestions which highly improved the manuscript. 


\section{Abstract}

In Sepia officinalis (Linnaeus, 1758), the digestive gland matures during the first month post-hatching while a shift from intracellular acid to extracellular alkaline digestion occurs. The purpose of this study was to investigate the possibility of using enzymatic ratios for the description of digestive system maturation in early life stages of S. officinalis. Secondly, it is intended to apply these new tools as eco-physiological indicators for understanding the impact of cuttlefish eggs' life history from different spawning sites of the English Channel on digestive performance of juveniles. An experimental rearing was performed over 35 days after hatching (DAH) on juveniles from wild collected eggs in 2010 and 2011. Four digestive enzyme activities and their ratios [i.e. trypsin, cathepsin, acid (ACP) and alkaline (ALP) phosphatase, ALP/ACP and trypsin/cathepsin] were studied along with histological features [e.g. internal yolk surface and digestive gland development]. The two enzyme ratios were good indicators of digestive system maturation allowing the study of the digestive gland's development. They were highly correlated to juveniles' weight increase and histological features of the gland in early DAH. These ratios described more accurately the shift occurring between the intracellular acid and the extracellular alkaline modes of digestion in S. officinalis and were more specific than separated enzyme activities. Their application as eco-physiological tools revealed that enzyme ratios reflected yolk content and digestive gland development in new hatching juveniles. Finally, ALP/ACP ratio was shown to be a powerful tool to describe growth performance of $S$. officinalis which is useful for aquaculture optimization.

Keywords: Sepia officinalis; early life stages; enzyme ratio; indicator; digestive gland; cathepsin; phosphatase; trypsin

\section{Introduction}

Cephalopods are a highly developed group of marine mollusks with digestive physiology that shares several similarities with that of fish. Indeed, the extracellular digestion occurs in the stomach, while keeping some characteristic features of their molluscan ancestry, with the intracellular digestion (Boucaud-Camou and Yim 1980; O’Dor and Webber 1986).

The digestion of proteins by intracellular enzymes in fish larvae is thought to aid in digestion to compensate for the lack of a functional stomach (Georgopoulou et al. 1985; Govoni et al. 1986; Cahu and Zambonino Infante 1995; Lazo et al. 2007). However, in cephalopods, this "ancestral" intracellular digestion is described at all life stages in parallel with the "advanced" extracellular digestion therefore both leading to a rapid growth of these animals due to the efficient assimilation of nutrients (Boucaud-Camou and Roper 1995; Swift et al. 2005). The combination of intracellular and extracellular digestion makes the cephalopods digestive system particularly performant. The efficiency of this digestive system is mostly attributed to the digestive gland and its multiple roles in digestion, namely enzyme secretion, absorption of molecules, intracellular digestion, nutrient and lipid storage as well as excretion of waste products, to 
mention only the main ones (Boucaud-Camou and Yim 1980; Boucaud-Camou and Boucher-Rodoni 1983; BoucherRodoni et al. 1987; Budelman et al. 1997; Semmens 2002; Martínez et al. 2011; Costa et al. 2014; Lopez-Peraza et al. 2014).

Given the carnivorous diet of cephalopods (Boucaud-Camou and Boucher-Rodoni 1983), the dominant enzymes are expected to be a suite of proteases. Cephalopod enzymatic activities, which are localized in the digestive system, were determined as non-specific proteolytic, $\alpha$-amylasic, alkaline and acid phosphatasic activities (Boucaud-Camou 1973; Boucher-Rodoni 1981; Perrin et al. 2004). The non-specific proteolytic activities include trypsin and cathepsin enzymes. Trypsin (EC 3.4.21.4) is a member of a large family of serine proteases, which specifically hydrolyses proteins and peptides at the carboxyl group of arginine and lysine residues and plays major roles in biological processes such as digestion and activation of zymogens of chymotrypsin and other enzymes (Kolodziejska and Sikorski 1996; Jellouli et al. 2009). Cathepsins are intracellular enzymes, mainly aspartic and cysteine endopeptidases, active at acid conditions (Morishita 1972; Gildberg 1988; Balti et al. 2010). Acid phosphatases (EC 3.1.3.2, ACP) are characteristic of lysosomes (Boucaud-Camou 1974), and alkaline phosphatases (EC 3.1.3.1, ALP) are membrane-bound enzymes that can be found in cell membrane in which the active transport takes place (Boucaud-Camou and Roper 1995). ACP and ALP catalyze the hydrolysis of various phosphate-containing compounds and act as transphosphorylases at acid and alkaline pHs, respectively (Mazorra et al. 2002; Lacoue-Labarthe 2010). These enzyme activities were observed in the digestive system of several cephalopod species such as Octopus maya (Aguila et al. 2007; Rosas et al. 2011; Martínez et al. 2011), Dosidicus gigas (Gárdenas-López and Haard 2009), Robsonella fontaniana (Pereda et al. 2009), Sepioteuthis lessoniana (Semmens 2002) and Sepia officinalis (Perrin et al. 2004; Balti et al. 2010; Lacoue-Labarthe et al. 2010) and are considered as key elements in the digestive process.

In cephalopods, enzyme activities are generally used by researchers in relation to diet and growth (Perrin et al. 2004; Le Bihan et al. 2006a; Pereda et al. 2009; Rosas et al. 2011), contaminants (Lacoue-labarthe et al. 2010; Le Pabic et al. 2015) or are localized to describe their function in the digestive system (Boucaud-Camou 1982; Boucaud-Camou and Roper 1995). Although some enzyme activities were used as environmental descriptors in relation with marine population dynamics (Bergeron et al. 2013), such approaches are still rare in cephalopods. In an ecological context, enzyme activities are expected to be highly variable; this could be one of the main reasons for this lack of studies. Howbeit, it is common for studies involving humans to use ratios as health indicators in physiological studies (e.g. lipoprotein or enzyme ratios). Lipoprotein ratios are used in cases of heart diseases (Fuduka et al. 2011; Soska et al. 2012) whereas enzyme ratios can be markers of liver fibrosis (Fabris et al. 2006; Shin et al. 2008) or age-related oxidative stress (Ozturk et al. 2012). In cephalopods, the only tools applied right now for trophic dynamics and 
ecological description are stable isotope ratios, lipids and fatty acids signature as well as trace metal accumulation (e.g. Jackson et al. 2007; Chouvelon et al. 2011; Lourenço et al. 2014). Therefore, enzymatic tools, and more particularly enzyme ratios, still need to be developed in ecological studies that have not been used for such purposes yet. The potential use of enzyme ratios as health indicators in cephalopods (e.g. describing growth performance or contaminants' impact on digestive system) is also important to be investigated.

The European common cuttlefish, Sepia officinalis (Linnaeus, 1758) lives in the Mediterranean and in the waters of the Eastern Atlantic from southern Norway to the north-western coast of Africa reaching the border limit between Mauritania and Senegal (Jereb et al. 2015). In the English Channel, the population of S. officinalis performs large migrations offshore in winter and inshore in spring for reproduction (Boucaud-Camou and Boismery 1991) and become mainly, but not exclusively, sexually mature at 2 years old (Gras et al. 2016). The littoral zones of the English Channel are thus important spawning locations for Sepia. Once mating occurs, cuttlefish lay their eggs on benthic structures in coastal waters, essentially between April and June and die shortly afterwards (Boucaud-Camou and Boismery 1991). The eggs then undergo local environmental conditions that influence their development (Bloor 2016). After hatching, juveniles stay in coastal waters until autumn migration offshore. These early-life stages affect life- history characteristics, distribution and abundance (Bouchaud and Daguzan 1989; Pierce et al. 2008; Bloor et al. 2013). Hence, early-life history is thus assumed to be one of the most critical phase in Sepia life cycle and is a key factor for recruitment success (Bloor et al. 2013). Finally, the digestive system of cuttlefish goes through a critical maturing phase during the first month of life. A transition from a predominant acid intracellular digestion to extracellular alkaline digestion occurs (Boucaud-Camou et al. 1985). Digestive gland cells, that are immature at hatching, are progressively filled with various cytoplasmic inclusions, such as vacuoles, lipid droplets and "balls" (digestive vesicles) while maturing (Boucaud-Camou and Yim 1980).

The present study investigates, for the first time, the possibility of using enzymatic ratios (as new indicators) for the description of the digestive system maturation in early life stages of $S$. officinalis. For that purpose, the activities of four enzymes, involved in intra- (i.e. cathepsin and ACP) and extracellular (i.e. trypsin, and ALP) digestion and their ratios (i.e. trypsin/cathepsin, ALP/ACP) were studied along with digestive gland histological observations. These selected enzymes were identified and commonly used in early-life stages of S. officinalis and are crucial during the digestive gland maturation (Boucaud-Camou 1982; Boucaud-Camou et al. 1985; Boucaud-Camou and Roper 1995; Perrin et al. 2004; Lacoue-labarthe et al. 2010; Le Pabic et al. 2015).

The aim of this work was to (1) update and complete the description of the main transitional process during the digestive gland maturation of $S$. officinalis (first month of life), (2) test the relevance of enzymatic ratios (i.e. ALP/ACP 
and trypsin/cathepsin) in digestive gland maturation and (3) use these enzymatic ratios as eco-physiological indicators and as indicators of growth performance. This work would allow developing and testing new eco-physiological indicators while refining the description of the main digestive gland maturation process of S. officinalis.

\section{Material and methods}

\subsection{Egg sampling and experimental juvenile growth survey}

Mature eggs (i.e. very swollen eggs indicating advanced embryonic development) of wild Sepia officinalis were collected from four sites among the main spawning grounds of cuttlefish in the English Channel (Boucaud-Camou et Boismery 1991; Dunn 1999). Two of them are located on the French coast [Agon Coutainville (AC; 4902`35”N, $\left.1^{\circ} 34^{\prime} 32^{\prime \prime} \mathrm{W}\right)$ and Bay of Seine (BS; 49 $\left.\left.18^{‘} 53^{\prime}{ }^{\prime} \mathrm{N}, 0^{\circ} 21^{\prime} 0^{\prime \prime} \mathrm{W}\right)\right]$ and two others on the UK coast [Torbay (TB; $\left.50^{\circ} 27^{\circ} 08^{\prime \prime} \mathrm{N}, 3^{\circ} 33^{\prime} 25^{\prime \prime} \mathrm{W}\right)$ and Selsey (SE; 50॰44`06'’N, 0`47’23’’W)] (Fig. 1). Between 1000 and 2400 eggs were sampled per site in July 2010 and 2011 and were transferred to the marine research center of the University of Caen Normandy (CREC, Normandy, France). Eggs were conditioned in boxes half filled with seawater and algae for stabilization during the transport. When the eggs came to the marine research center, they were placed on sieves $(0.36 \mathrm{x}$ $0.28 \mathrm{~m}, 1-\mathrm{mm}$ mesh size) distributed in large tanks containing circulating seawater at a temperature of $18.5 \pm 0.5^{\circ} \mathrm{C}$ (Semi-closed system previously described by Koueta and Boucaud-Camou 1999).

In order to avoid the use of premature juveniles resulting from transport stress, one can generally see it from their remnant external yolk, eggs were acclimatized for 3 days prior to juveniles' collection among experimental rearing (i.e. All juveniles hatched during the 3 days of eggs acclimatization were automatically removed from the tanks). Mature eggs were specifically chosen so that the major incubation period would be achieved in the original natural spawning site. After hatching, juveniles were reared for 35 days between July and September 2010 and 2011. In order to synchronize the launch of all rearing groups (i.e. BS, AC, TB and SE), a large number of mature eggs were collected from spawning sites (i.e. between 1000 and 2400 eggs/ site). Throughout the hatching period, hatching peaks were observed on specific days. Juveniles used for the growth survey were collected during these peaks so that to have 150 cuttlefish per site which hatched on the same day (i.e. being the same age). Even though we managed to have 150 juveniles/site having the same age to be launched for rearing, it was difficult to have juveniles from the four sites (i.e. $\mathrm{BS}, \mathrm{AC}, \mathrm{TB}$ and SE) launched for rearing on the same date. It is worth noting that in order to avoid any bias due to the delay in launching the rearing process between sites (i.e. a maximum of two weeks delay), a strict control of the abiotic conditions was constantly applied; moreover, the food (i.e. Crangon crangon) was prepared in June and frozen at $-80^{\circ} \mathrm{C}$ in order to have the same food source and quality for all. 
Cuttlefish from each site were placed into six rectangular sieves $(0.36$ x $0.28 \mathrm{~m} ; 1 \mathrm{~mm}$ mesh size; 25 juvenile /sieve).

Sieves were randomly distributed across three tanks thus mixing the sieves with juveniles from different origins in order to avoid any bias related to the parameters of the tank (e.g. controlled temperature). Cuttlefish were fed ad libitum with frozen shrimps C. crangon. Mean water temperature was $19.4 \pm 0.1$ in 2010 and $19.3 \pm 0.2$ in 2011 ; the rearing system allowed $80 \%$ renewal of seawater per day so as to avoid changes in salinity content, $\mathrm{pH}$ as well as accumulation of nitrogen compounds.

Juvenile were sampled 0, 7, 14, 21, 28 and 35 days after hatching (DAH). Weight measurements were conducted on 24 juvenile cuttlefish/site/DAH with a Denver Instrument balance ((Digital blanc, Washington, precision of $0.001 \mathrm{~g})$. For enzymatic assays, 5 juvenile cuttlefish/site/DAH were anesthetized in a $2 \%$ ethanol solution in seawater, which is widely used as an anaesthetic agent in cephalopods (Fiorito et al. 2015). Once anaesthetized, i.e. observable decrease of locomotor activity and loss of normal posture, the animals were frozen in liquid nitrogen and kept at $-80^{\circ} \mathrm{C}$ until biochemical analysis. This quick euthanasia method is adequate to avoid animal suffering with minimum pain and distress (Fiorito et al. 2015). For histological experiments, 6 and 10 juveniles (in 2010 and 2011 respectively) were anesthetized in a $2 \%$ ethanol solution in seawater, fixed in a Davidson's solution ( $10 \%$ glycerol, $20 \%$ formaldehyde, $30 \%$ ethanol, $40 \%$ filtered seawater) for $24 \mathrm{~h}$ at $4{ }^{\circ} \mathrm{C}$ and then transferred in a $70 \%$ ethanol storage solution.

\subsection{Enzymes extraction and assays}

\subsubsection{Enzyme extraction}

Sampled juveniles (i.e. 5 juvenile cuttlefish/site/DAH) were individually weighed before being separately grounded in liquid nitrogen. The digestive enzymes are highly concentrated in the digestive system with the digestive gland playing a major role in their secretion (Boucaud-Camou et al. 1985). Several authors have investigated the digestive enzymes' evolution in early life stage of S. officinalis, using the entire animal to reflect the digestive system maturation in relation to the animal's growth performance (Koueta et al. 2000, Perrin et al. 2004, Le Bihan et al. 2006a, Le Pabic et al. 2015). The same approach is applied here for enzymatic assays.

Powder obtained after grinding was homogenized in a known amount $(0.1 \mathrm{~g}$ to $10 \mathrm{ml})$ of Tris buffer $\mathrm{pH} 8$ (10 mM Tris$\mathrm{HCl}$ and $150 \mathrm{mM} \mathrm{NaCl}$ ) and stored at $4^{\circ} \mathrm{C}$ for 1 hour. The mixture was then centrifuged for $10 \mathrm{~min}$ at $15000 \mathrm{~g}$ and $4^{\circ} \mathrm{C}$. The supernatant was used for digestive enzyme assays and for determination of total protein concentration.

\subsubsection{Total protein concentration}

The total protein content was assayed according to the Bradford method (1976) using Bovine Serum Albumin (SigmaAldrich, France) as standard. 
Trypsin activity was measured according to Tsunematsu et al. (1985) using $1 \mathrm{mM}$ Na-benzoyl-Arg-p-nitroanilide as substrate in a $0.1 \mathrm{M}$ Tris buffer at $\mathrm{pH}$ 9. Twenty $\mu$ l of supernatant were added to $100 \mu \mathrm{l}$ of substrate in triplicates in sterile 96-well flat bottom plates (BD, USA) and samples were incubated for 1 hour at $25^{\circ} \mathrm{C}$. The final absorbance was recorded at $410 \mathrm{~nm}$ using Mithras LB940 luminometer (Berthold, Thoiry, France) and the enzyme activity was expressed as trypsin specific activity (U.mg $\operatorname{prot}^{-1}$ ) where one enzymatic activity corresponds to $1 \mu \mathrm{mol}$ of $\mathrm{pNa}$ formed. $\min ^{-1}$.

Cathepsin activity was measured according to Bonete et al. (1984) using $100 \mu \mathrm{l}$ of supernatant, $50 \mu 1$ of $0.4 \mathrm{M}$ acetate buffer at $\mathrm{pH} 4$ and $50 \mu \mathrm{l}$ of $2 \%$ (w/v) haemoglobin solution. In parallel, intrinsic proteolytic end products were measured by replacing $50 \mu 1$ of $2 \%$ haemoglobin by Milli-Q water. Samples were then incubated at $37{ }^{\circ} \mathrm{C}$ for 1 hour. The reaction was stopped by adding $1 \mathrm{ml}$ of $3 \%(\mathrm{w} / \mathrm{v})$ trichloroacetic acid. After $10 \mathrm{~min}$, the assays were centrifuged at $800 \mathrm{~g}$ for $10 \mathrm{~min}$ at $4^{\circ} \mathrm{C}$. Fifty $\mu \mathrm{l}$ aliquots were used to estimate the released proteolytic end products by using the Bradford (1976) method with Bovine Serum Albumin (Sigma-Aldrich, France) as standard. The activity was expressed as cathepsin specific activity (U.mg $\left.\operatorname{prot}^{-1}\right)$.

Total acid and alkaline phosphatase (respectively ACP and ALP) activities were respectively determined according to Moyano et al. (1996) and Principato et al. (1982) using p-nitrophenyl-phosphate 2\% as substrate in a 1 M Tris buffer at $\mathrm{pH} 3$ for ACP and $\mathrm{pH} 10$ for ALP. For both activities, $10 \mu \mathrm{l}$ of supernatant were added to $10 \mu \mathrm{l}$ of substrate in 96-well flat bottom plates (BD, USA). After 30 min of incubation at $25^{\circ} \mathrm{C}, 100 \mu \mathrm{l}$ of $\mathrm{NaOH} 1 \mathrm{M}$ were added to stop the reaction and reveal the color. The absorbance was measured at $405 \mathrm{~nm}$ using Mithras LB940 luminometer. Total acid and alkaline phosphatase activities were expressed as specific activity (U.mg prot ${ }^{-1}$ ) where one enzymatic unit corresponds to $1 \mu \mathrm{mol}$ of $\mathrm{p}$-nitrophenol formed. $\mathrm{min}^{-1}$.

\subsubsection{Enzymatic ratios}

During the first month post-hatching, a shift from predominant acid intracellular digestion to extracellular alkaline digestion was observable in S. officinalis juveniles (Boucaud-Camou et al. 1985). Enzymatic ratios were calculated in order to describe this shift between intracellular digestion carried out by enzymes acting in acidic medium and extracellular digestion carried out by alkaline enzymes. Two types of ratios were calculated, one between the two proteolytic enzyme activities (trypsin/cathepsin) and one between the two phosphatase activities (ALP/ACP).

\subsection{Histology}

A histological study of the maturation of the digestive gland was undertaken in parallel to enzymatic assays. For this purpose, the samples stored in $70 \%$ ethanol solution were washed, dehydrated and embedded in paraffin. Serial sections of $5 \mu \mathrm{m}$ were cut with a manual rotary microtome Leica RM2135 (Leica, Nanterre, France), processed and stained with 
Prenant-Gabe's trichrome according to a classical protocol (Gabe 1968). Digital pictures and cell measurements of the digestive gland were achieved with the Nikon C system combining Eclipse 80i microscope / DXM1200-C digital camera and NIS-elements D 3.0 software.

The maturation of the digestive gland was assessed from 0 to $35 \mathrm{DAH}$ with special emphasis on the hatching day (i.e. D0) reflecting the incubation conditions in the different spawning sites with no experimental interference. In $0 \mathrm{DAH}$ juveniles, internal yolk and digestive gland surfaces (respectively IYS and DGS, $\mathrm{mm}^{2}$ ) were measured (Fig. 2). The digestive gland development (DGD, \%) was estimated according to the following equation:

DGD $(\%)=[\mathrm{DGS} /(\mathrm{DGS}+\mathrm{IYS}] \times 100$

From 0 to $35 \mathrm{DAH}$, cytological features, that are specific to maturing digestive cells such as the mean number of "balls" (proteinaceous inclusions characteristic of most cephalopods)/cell (NBC) (Fig. 2) and the mean digestive cell length $(\mathrm{CL}, \mu \mathrm{m})$, were estimated from observations of 50 digestive cells/individual using 6 juveniles/DAH/site that had been sampled in 2010 .

\subsection{Statistical analysis}

All results are given as mean \pm standard error. For statistical analysis, preliminary tests of normality (Shapiro test) and homoscedasticity (Bartlett test) allowed the use of parametric methods. Biological responses (weight, enzymatic activities, enzymatic ratios and histological features) were compared across samples (see Table S1 which synthetizes the number of samples/analysis). Two-ways ANOVA (for factors site and age) were used for samples of the same year. The statistical significance threshold was set at $p<0.05$. When significant differences were observed, then a post hoc Tukey test was used to look for homogenous groups of batches. An ANCOVA analysis was conducted for inter-annual comparisons (2010-2011) of growth evolution, enzymatic activities and enzyme ratios.

At hatching day (0 DAH), differences between juveniles were sought in relation to the origin of the eggs (i.e. spawning sites: BS, AC, TB and SE). Differences in enzymatic variables were analyzed in two steps. In the first step, the matrix describing enzyme activities and ratios at 0 DAH was analyzed using a MANOVA analysis to test significant differences between origin sites. In a second step, a Linear Discriminatory Analysis (LDA) was performed to display juveniles in the plane of the first discriminant axes and to visualize site differences.

During the first month post-hatching (i.e. 0 - $35 \mathrm{DAH}$ ) the correlations between average juvenile growth (i.e. weight and age), digestive enzyme activities and ratios, and histological features (i.e. NBC and CL) were analyzed using a Principal Component Analysis (PCA) in order to determine which variables contributed most to the description of changes in physiology . 
Spearman rank correlation tests were also performed at $0 \mathrm{DAH}$ and during the first month post-hatching (i.e. 0 - 35 DAH) to test the relationships between variables used in the LDA and those used in the PCA.

R software and packages were used for statistics and graphics (Fox and Weisberg 2011; Hervé 2012; R Core Team 2012).

\section{Results}

\subsection{Growth survey}

Cuttlefish growth was monitored on reared juveniles hatched from eggs collected at four different spawning sites of the English Channel in 2010 and 2011 (Fig. 3a, b). The general profile of juveniles' growth showed a "no net growth" phase between 0 and 7 DAH. Then a significant weight increase was observed between 14 and 35 DAH (Table 1). Slopes fitted to the weight natural logarithm were significantly lower in 2011 (mean weight of $1.5 \mathrm{~g}$ at $35 \mathrm{DAH}$ ) than in 2010 (mean weight of $2 \mathrm{~g}$ at $35 \mathrm{DAH})$, thus revealing a significantly lower growth rate in $2011(\mathrm{ANCOVA}, F(1,6)=$ 62.86, $\left.p_{\text {value }}=2.14 \mathrm{e}^{-04}\right)$.

The main spatial difference in juvenile's weight was observed between BS and AC in 2010 (Fig. 3a) and in 2011 (Fig. 3b). This difference was not observed at 7 DAH but the weight distribution reappeared afterwards from 14 until 35 DAH with marked significant differences at 28 and 35 DAH (Table 1). The UK juveniles (i.e. TB and SE) showed no significant difference in weight (Table 1). When compared to French sites (i.e. BS and AC), The UK juvenile's weight distribution appeared to be closer to BS juveniles.

\subsection{Digestive enzyme activities and ratios}

\subsubsection{Enzymatic activities: general profile description}

Trypsin mean activity varied between 0.5 and 1.6 IU.mg prot ${ }^{-1}$ during both monitoring years (Fig. S1a, b). In 2010

(Fig. S1a), an increase of this activity was observed between 0 and 7 DAH then this activity was stabilized until 35 DAH. In 2011 (Fig. S1b), a significant increase was noticed between 0 and 14 DAH (Table S2) followed by an important variability in activities between 14 and 35 DAH. Cathepsin mean activity varied between 5 and 25 IU.mg $\operatorname{prot}^{-1}$ (Fig. S1c, d) during the two monitoring years of the study. In both years, a significant increase of cathepsin activity was described during the first week (Table S2) followed by a decrease in activity and a stabilization afterwards between 21 and 35 DAH. The trypsin/cathepsin ratio (Fig. 4a, b) had a general profile that varied between the two years. However, a significant peak of this ratio was observed at $28 \mathrm{DAH}$ for both years (Table 2). 
Mean alkaline (ALP) and acid (ACP) phosphatase activities measured from 0 to $35 \mathrm{DAH}$ varied respectively between 1.7 and 4 IU.mg prot $^{-1}$ for ALP and between 6 and 13 IU.mg prot ${ }^{-1}$ for ACP (Fig. S1e to S1h). ALP activity profiles

(Fig. S1e, f) showed a significant increase in early DAH then a stabilization until 35 DAH (Table S2). ACP activity profiles (Fig. S1g, h) showed a significant increase of activity, between 0 and 7 DAH, then a significant decrease up to 35 DAH (Table S2) with a stabilization phase from 21 DAH observed only in 2010 (Fig. S1g). ALP/ACP ratios (Fig. 4c, d) revealed a significant increase of this ratio up to 35 DAH in both years of study (Table 2).

The ANCOVA analysis applied on these enzyme activities revealed (i) a higher decrease in cathepsin and ACP activities after 7 DAH in 2010 (Fig. S1c, g) compared to 2011 (Fig. S1d, h) [ANCOVA, cathepsin: $F(1,6)=7.08, p_{\text {value }}$ $=0.037$;CP: $\left.F(1,6)=18.31, p_{\text {value }}=0.005\right]$ and (ii) a higher slope in ALP/ACP ratio in 2010 (Fig. 4c) compared to 2011

(Fig. 4d) (ANCOVA, $\left.F(1,6)=5.41, p_{\text {value }}=0.049\right)$.

\subsubsection{Comparing enzymatic activity between sites}

Trypsin mean activity did not reveal any significant differences between sites on the same DAH (Fig. S1a, b and Table S2). In contrast, cathepsin activity exhibited significant differences between sites at 0 and 7 DAH (Fig. S1c, d and

Table S2). Two groups were observed in the two years of study, the first including AC and SE and the second including BS and TB. Indeed, at hatching day (0 DAH), SE and AC had significantly higher cathepsin activity than TB and BS and this distribution was maintained at day 7. These two groups were also observed with trypsin/cathepsin ratios (Fig. 4a, b) at 0 and 7 DAH.

ALP and ACP activities did not give a clear pattern related to spawning sites (Fig. S1e, f, g, h). However, when ALP/ACP ratio was applied (Fig. 4c, $\mathbf{d}$ ), the same two groups were formed as observed for trypsin/cathepsin ratios, the first including AC and SE showing lower ALP/ACP ratio at 0 and $7 \mathrm{DAH}$; the second including BS and TB with a higher ALP/ACP ratio. These differences tended to disappear afterwards until $35 \mathrm{DAH}$.

\subsection{Histological features of the maturing digestive gland}

\subsubsection{Histological features at hatching (O DAH)}

Internal yolk surface (IYS) (Fig. 5a, b) and digestive gland development (DGD) (Fig. 5c, d) distribution were similar in the two years. Two juvenile groups appeared at 0 DAH, one including BS and TB juveniles with lower IYS but higher DGD as compared to the second group with AC and SE. 
Mean number of "balls" per cell (NBC) (Fig. 6a) and digestive cell length (CL) (Fig. 6b) were only studied in 2010, due to the absence of clear patterns in relation to the origin of juveniles (i.e. no significant differences were observed in CL and NBC when comparing different sites at the same DAH at the exception of AC at 14 DAH). CL significantly increased up to 28 DAH then decreased from 28 to 35 DAH (Table 3). "Balls" were only observed from 7 DAH. From this stage, NBC started to increase up to $21 \mathrm{DAH}$ and then stabilized between 21 and $35 \mathrm{DAH}$, as observed for enzyme activities.

3.4 Multivariate analysis of enzyme and histological descriptors

\subsubsection{Site related differences at hatching day}

The MANOVA performed on juvenile enzyme activities and ratios showed significant differences $\left(p_{\text {value }}=1 \cdot 12 \cdot 10^{-6}\right)$ between spawning sites. The descriptive LDA (Fig. 7) highlighted on the first axis the differences between the origin sites (almost $80 \%$ of the variance were represented on the first axis - Fig. 7b). Juveniles from BS and TB appeared clearly separated from AC and SE juveniles (Fig. 7a). The correlation circle (Fig. 7c) provided additional information explaining the underlying differences of this separation between sites. The first axis was explained by enzyme ratios and cathepsin activity. Higher enzyme ratios in BS and TB set them apart from AC and SE which had significantly lower enzyme ratios and higher cathepsin activities. The results obtained here are in agreement with the previously made observations of the histological features (Fig. 5) and enzymatic ratios at 0 DAH (Fig. 4). Spearman rank correlation test revealed that the enzyme ratios were highly correlated to DGD and inversely correlated to IYS at hatching (Table S3). The shift between IYS and DGD was shown by the inverse correlation between each other (Table S3). The digestive gland maturation at hatching (i.e. higher DGD) was better described using enzyme ratios (i.e. ALP/ACP and trypsin/cathepsin) rather than with each enzymatic activity either alkaline (i.e. ALP and trypsin) or acid (i.e. ACP and cathepsin). Ratios and histological features showed higher R-squared and lower $p_{\text {values }}$ in the correlation matrix between variables observed at 0 DAH (Table S3). Finally enzyme ratios provided a measure of the maturation stage of the digestive gland at 0 DAH similar to what can be achieved with histological observation.

\subsubsection{Principal Component Analysis (PCA)}

The relationship between juveniles' growth, enzymatic activities, enzyme ratios and histological features (i.e. NBC and CL) was investigated with a PCA (Fig. 8). With these variables, the first two dimensions of the PCA accounted for almost $68 \%$ of the variability in the dataset. The first dimension, which accounted for $49.08 \%$ of the variability, represented mainly changes in the enzyme ratios, in weight and in histological features (i.e. NBC and CL). The second 
dimension, which accounted for $18.85 \%$ of the variability, explained mainly enzyme activities. Projections in the first plane of the PCA revealed four groups of variables in the correlation circle (Fig. 8b). The first two groups included enzyme activities with a high correlation between the intracellular acid enzymes from one side (i.e. ACP and cathepsin) and a high correlation between the extracellular alkaline enzymes from the other side (i.e. ALP and trypsin) (see also Spearman rank correlations in Table S4). The third group showed that the enzyme ratios were highly correlated with the juvenile's growth (i.e. weight) and with histological features (i.e. NBC and CL). Considering the importance of the balance between alkaline (i.e. ALP and trypsin) and acid (i.e. ACP and cathepsin) enzyme activities in S. officinalis' early life stages, the use of enzymatic ratios (i.e. ALP/ACP and trypsin/cathepsin) has increased the significance of correlations between the enzyme ratios and the histological features that describe the digestive gland maturation (see Spearman rank correlations in Table S4). The fourth group was formed by the juveniles' survival which did not reveal significant correlations with the variables included in the PCA (see Spearman rank correlations in Table S4). It is worth noting that samples were reared in the same condition during the first month and that the projection of the individual samples on the plane formed by the first two principal axes (Fig. 8a) showed no pattern related to juveniles' origin site, at the exception of 0 DAH juveniles' differences already revealed with the Linear Discriminatory Analysis (Fig 7).

The correspondence between plot a and plot b in the Fig. 8 allows for further analysis of temporal changes. The colored clusters in Fig. 8a were mainly related to cuttlefish age evolution (i.e. from 0 to 35 DAH), evolving clockwise from the bottom left quadrant to the bottom right quadrant. The red and green clusters (Fig. 8a), which were respectively juveniles' samples at 7 and 14 DAH, showed a high correlation with the ACP and cathepsin enzyme activities (Fig. 8b), underlying their importance during the cuttlefish first days after hatching. The alkaline enzymes (i.e. trypsin and ALP), the histological features of the maturing digestive gland (i.e. NBC and CL) and the enzyme ratios showed higher correlation with the older cuttlefish, aged 21 to 35 DAH and respectively represented by blue, light-blue and purple clusters in the right panel of the PCA (Fig. 8a). These observations represented the changes that were occurring during the first month post hatching in cuttlefish juveniles, transitioning from an important role of intracellular digestive enzymes during yolk digestion to an increasing role of extracellular digestive enzymes with the maturing digestive gland.

\section{Discussion}

In the course of this work, a complete update of the main transitional process knowledge, occurring with the maturation of digestive gland in Sepia officinalis, was conducted. This information was used to validate the suitability of developed indicators (i.e. enzymatic ratios) and was then used to understand the impact of life history of eggs (i.e. maternal and 
ecological effects) on digestive performance of $S$. officinalis early-life stages. The structure of the discussion thus follows the three aspects of this study with (i) knowledge update of the main transitional processes during digestive gland maturation, (ii) the test of indicators (i.e. enzymatic ratios) to describe digestive gland maturation and (iii) the application of these indicators to an ecological case study and for aquaculture optimization.

\subsection{Main transitional process during digestive gland maturation}

The digestive gland of cuttlefish develops in the first month after hatching until it reaches its definitive adult physiology (Yim and Boucaud-Camou 1980; Boucaud-Camou and Boucher-Rodoni 1983). In this process, the digestive gland goes from a state of reserve and yolk distribution organ to a state of an organ responsible for the processing of ingested food (Boletzky 1975). Boucaud-Camou et al. (1985) defined three periods in the early-life stages of cuttlefish S. officinalis. The embryonic phase, which starts with the egg development and lasts until juvenile's first meal. In this first phase, food is only provided by the yolk which is digested by the intracellular enzymatic activities of the yolk syncytium. The post-embryonic phase, which begins with the first meal, shows a coexistence between the embryonic mode of nutrition (yolk digestion) and the post-embryonic mode (capture of prey and extracellular digestion in the digestive tract). The third phase (i.e. juvenile-adult phase) is characterized by the acquisition of an adult pigmentation and physiology of the digestive gland. In this study, the transition from embryonic to post-embryonic digestion was observed at 7 DAH whereas transition from post-embryonic to the juvenile-adult phase was observed at $21 \mathrm{DAH}$.

\subsubsection{Embryonic to post-embryonic digestion transition}

The transition between embryonic and post-embryonic digestion occurred during the first week of juveniles' life when internal yolk reserve is being digested and juveniles start exogenous feeding by catching preys (i.e. around day 4). During this transition period, a “no net growth" phase has been observed with a decrease in juveniles' survival (Fig. 9). A low growth in early post-hatching days has been described in several cephalopod species such as Loligo opalescens (Vidal et al. 2002), O. maya (Moguel et al. 2010) and S. officinalis (Boucaud-Camou and Boucher-Rodoni 1983). Boucaud-Camou and Boucher-Rodoni (1983) attribute this delay in growth to the fact that the extracellular digestion has not started because of yolk absorption. However, from a physiological point of view, several changes take place. A significant increase in enzyme activities (i.e. trypsin, cathepsin and phosphatases) was observed between 0 and 7 DAH. In the digestive gland cells, digestive vesicles known as "balls" emerged at 7 DAH (Fig. 6a). These are densely staining spheres containing digestive enzymes that are released in the stomach for primary digestion (Boucaud-Camou and Yim 
1980; Boucaud-Camou and Boucher-Rodoni 1983). Their appearance is a sign of the establishment of extracellular digestion which induced the increase in extracellular enzyme activities (i.e ALP and trypsin) between 0 and 7 DAH. An increase in cathepsin and acid phosphatase activities was also registered during the embryonic phase, from 0 to 7 DAH, and mainly marked by cathepsin activity. Umezawa (1982) presented evidence that the most abundant yolk protein is primarily and proteolytically processed by the cathepsin-B-like enzyme which was identified in S. officinalis digestive gland (Le Bihan et al. 2006b). The optimal pH for this enzyme activity is low to ensure its stability (Le Bihan et al. 2006b) while pH appears to be a key regulator of yolk degradation (Fagotto 1990, Martínez et al. 2011). The yolk platelets are initially neutral but become acidic on a later phase during development, causing pro-enzyme maturation and yolk degradation (Fagotto 1991). These mechanisms were described in cephalopods which probably shared the same regulatory enzymatic mechanism for yolk degradation (e.g. O. maya; Martínez et al. 2011). Peaks in digestive enzyme activity in O. maya juveniles in early DAH (Moguel et al. 2010) coincide well with the decrease in density of yolk platelets (Martínez et al. 2011). Thus, in S. officinalis, the increase in cathepsin and in ACP activities in the first week post-hatching could be a result of yolk acidification thus inducing cathepsin pro-enzyme activation. Moreover, the increase of these enzyme activities could also be supplemented by the synthesis of de novo enzymes (Boucaud-Camou and Yim 1980; Lacoue-Labarthe et al. 2010; Costa et al. 2014). Lacoue-Labarthe et al. (2010) suggested this hypothesis after studying the cathepsin and ACP activities during egg development of S. officinalis and after having observed an important increase of these activities in the final days before hatching. The increase in cathepsin and ACP activities revealed in this study after hatching seems to be a continuum of increasing activity of these enzymes in the post hatching phase, with a peak observed at 7 DAH (Fig. 9).

\subsubsection{Transition from post-embryonic to juvenile-adult digestion}

The transition from post-embryonic to juvenile-adult digestion was observed at $21 \mathrm{DAH}$ and corresponded to the establishment of extracellular digestion with exogenous feeding. The transition at 21 DAH indicates also a reversal in juveniles' survival trend. Survival decrease from embryonic phase up to the end of the post-embryonic phase reaching a rate of less than $95 \%$ of survival at 21 DAH. After $21 \mathrm{DAH}$, the juveniles' survival rate starts to increase (Fig. 9). The beginning of exogenous feeding is a major characteristic of the post-embryonic phase and induces the start of exponential growth (Boucaud-Camou et al. 1985) as observed after 7 DAH (Fig. 9). The first meal triggers the secretory activity of the digestive gland (ensured by the "balls" vesicles), while yolk is still being digested by the yolk syncitium (Boucaud-Camou and Boucher-Rodoni 1983). In this study, "balls" could be seen starting 7 DAH and their number increased rapidly before stabilizing from $21 \mathrm{DAH}$, similarly to digestive cell length (Fig. 9). As for enzymes, a decrease 
in intracellular acid enzymes (i.e. ACP and Cathepsin) is detected during the post-embryonic phase while extracellular alkaline enzymes (i.e. ALP and trypsin) starts to stabilize. After $21 \mathrm{DAH}$, extracellular and intracellular enzymes showed stabilized trends during the juvenile-adult phase, at the exception of the acid phosphatase that decreased up to 35 DAH. A stabilization phase is observed in enzyme activities of cephalopods when the digestive system matures (Solorzano et al. 2009). The appearance of well-developed digestive gland cells and plenty of "balls" between 21 and 35 DAH demonstrated that $S$. officinalis reached its digestive maturity when the enzyme activity was stable. However, the balance between extracellular and intracellular enzyme activities, mainly described with ALP/ACP ratio, did not seem to be fully mature at $21 \mathrm{DAH}$ as this ratio continued to increase up to $28 \mathrm{DAH}$. ALP/ACP revealed a constant increase between hatching day $(0 \mathrm{DAH})$ and $28 \mathrm{DAH}($ Fig. 9). This ratio permitted to describe the fine adjustments that occur during the first month post-hatching in S. officinalis between the two complementary modes of digestion (i.e. intracellular and extracellular digestion).

\subsection{Enzymatic ratios as indicators of digestive gland maturation}

The parallel between enzyme activities and digestive system maturation has been made in cephalopods such as $S$. officinalis (Boucaud-Camou 1982; Boucaud-Camou and Roper 1995; Perrin et al. 2004). However, to our knowledge, up to now no study has used enzyme ratio to characterize digestive system maturation.

\subsubsection{Indicators applied to new hatching juveniles (O DAH)}

The transition from dependence on maternally derived yolk reserves to independent active feeding represents a critical period in the early-life history of cephalopods (O’Dor and Wells 1975; Vecchione 1987; Boletzky 1989). At hatching time, cuttlefish juveniles have important yolk reserves that enable them to survive until exogenous feeding is established (Boucher-Rodoni et al. 1987). Estimating these yolk reserves is thus important to get an idea of the survival capacities of juveniles. In this study, histological observations were achieved in parallel with enzymatic assays in order to look into the correlations between histological features and enzyme ratios. ALP/ACP and trypsin/cathepsin ratios were found to be inversely correlated with internal yolk surface (IYS) and highly correlated with digestive gland development (DGD) at 0 DAH (Table S3). At hatching, the digestive gland of S. officinalis is being formed and replaces the IYS during maturation of the digestive system (Boucaud-Camou et al. 1985; Boucher-Rodoni et al. 1987). Thus, the ALP/ACP and trypsin/cathepsin ratios appeared to be very good indicators of the development of the digestive system in new hatching juveniles. The higher these ratios are, the more developed is the digestive gland and inversely, lower ratios are correlated with higher yolk reserves. 


\subsubsection{Indicators used to describe digestive gland maturation during the first month post-hatching (0 to 35 DAH)}

The adjustment in enzymatic activities that occurs during the first days post-hatching is a signal of juvenile digestion changing to adult digestion (Yim and Boucaud-Camou 1980; Vecchione and Hand 1989; Perrin et al. 2004). In this study, digestive gland maturation was well described by the ALP/ACP and trypsin/cathepsin ratios (Fig. 8). These ratios were highly correlated with juvenile age and weight increase up to 35 DAH (Fig. 8) even if the correlation was less noticeable with Trypsin/cathepsin ratio (Table S4). These enzyme ratios were also highly correlated with digestive gland maturing features (i.e. CL and NBC). Enzyme ratios are thus good indicators to describe the digestive system maturation in early life stages of cuttlefish. These ratios were found to be more specific than separated alkaline or acid activities for the description of digestive system maturation (Fig. 8). By integrating the acid activities into the establishment of the alkaline digestion with the digestive system maturing, the enzymatic ratios reflected the balance made between the two digestion modes (intracellular and extracellular digestion) during the first month post-hatching. The switch between the initial intracellular acid digestion into extracellular alkaline digestion in cuttlefish is best represented with these ratios and especially with the ALP/ACP ratio. This approach is very promising as it can give additional information on the digestive system maturation using simple tools.

\subsection{Use of enzyme ratio indicators in ecology and aquaculture optimization}

\subsubsection{Indicators applied to an ecological case study}

The development of tools such as enzyme ratio indicators to investigate the spatial digestive performance capacity of cuttlefish juveniles is much needed. This approach could lead in the future to a greater understanding of the relationship between stock abundance and early life history of S. officinalis in coastal habitats. Understanding the contribution of spawning sites to the recruited stock is still not well explained and the physiological performance of juveniles in those sites could be a key information to elucidate that.

The transition from the embryonic to post-embryonic stage was highly dependent on the juveniles' internal yolk content. This seemed to be influenced by the eggs' origin (i.e. spawning site) and thus, by the mother yolk deposit in them and afterwards, by the conditions of incubation of the eggs in the various sites. If a mother is able to predict the quality of her offspring's environment, she may increase their survival chances by adjusting their phenotype to the expected conditions (Segers and Taborsky 2010). Several examples of such maternal effects have been reported, demonstrating a wide range of mechanisms by which females can alter offspring phenotype by adapting to the environment (De Fraipont et al. 2000; Eising et al. 2001; Uller et al. 2007) and thus influencing the quality of egg 
content as described in $O$. vulgaris (Lourenço et al. 2014). Such hypotheses suggest that the female cuttlefish would adjust the yolk content in eggs depending on the environmental parameters where eggs are laid (such as the availability and access to prey for juvenile cuttlefish). Higher yolk content would enable better chances of survival of offsprings in an environment that is not rich in preys. It is good to know that, at hatching, the digestive gland of S. officinalis is still developing and digestive cells are still undifferentiated as most of them being immature (Yim and Boucaud-Camou 1980). At hatching time, the nutrients are exclusively obtained from the yolk by the digestive activity of the yolk syncitium (Boucaud-camou et al. 1985). In this study, the internal yolk content of juveniles at hatching was observed to be stable in space (i.e. AC and SE always had a significant higher yolk content than BS and TB) and time (i.e. differences were observed during the two years of study). These differences were also revealed by the enzyme ratios (Fig. 7) due to the high correlation between enzyme ratios and histological features at hatching (i.e. DGD and IYS) (Table S3). Despite the mother effect on eggs yolk content, many physico-chemical factors may have influenced the observed spatio-temporal distribution of internal yolk content in juveniles. Physico-chemical factors play an important role in the early life stages of Sepia (Bloor 2016) and may locally influence the incubation time of the eggs. Embryonic development of many cephalopods has been shown to be highly temperature-dependent as eggs develop faster in warmer waters (Semmens et al. 2007); this influences the amount of remaining yolk at hatching (Bouchaud 1991). The observed spatio-temporal distribution of internal yolk content in juveniles is hence a result of a combination between the amount of yolk deposited by the mother when laying eggs and the local environmental parameters during incubation period.

During the first phase of transition from an embryonic to a post-embryonic stage, the internal yolk reserve (IYS) and the digestive gland development (DGD) helped understanding the variability of enzyme ratios and juveniles' growth. Higher IYS advantages AC and SE in the first transitional period (i.e. from 0 to $7 \mathrm{DAH}$ ). This was mirrored by the absence of significant differences in juveniles' weight at 7 DAH even though significant weight differences were registered at $0 \mathrm{DAH}$ (Fig. 3). But this advantage was temporary as the extracellular alkaline digestion was taking place more rapidly in BS and TB during the same period. The DGD was already different at hatching and the ALP/ACP and trypsin/cathepsin ratios highlighted a faster maturation of the digestive system in BS and TB juveniles since ratios were greater at 0 and 7 DAH compared to those of AC and SE.

During the post-embryonic phase, weight differences between juveniles from different spawning sites, which were already described at 0 DAH reappeared at 14 DAH (Fig. 3). However, in 2010, the difference at 0 DAH was significant between BS juveniles and the other three sites. At 14 DAH, SE and TB showed a greater growth compared to AC juveniles as their weights became closer to BS juveniles. The advantage gained by SE and TB can be explained in two 
ways. SE juveniles had significantly more IYS than the other three sites, which induced higher intracellular acidic activities in the first phase of growth post-hatching. At 14 DAH, SE presented a high ALP/ACP ratio, similar to those found in BS and TB juveniles, whereas AC had a significantly lower ratio. Thus having the advantage in the first phase in intracellular digestion, juveniles of SE have had a DGD maturation equivalent to BS juveniles at the beginning of the post-embryonic phase. This maturation was reached only after 21 days in AC juveniles, which is later than those of the other sites. Intracellular acidic (with higher IYS) and extracellular alkaline (with higher ALP/ACP ratio) digestion helped understanding the higher growth of SE juveniles between 7 and 14 DAH. Similarly, TB juveniles had a higher DGD at 0 DAH when compared to AC juveniles and higher ALP/ACP which gave them the advantage in the second transitional phase.

Differences between cuttlefish batches were particularly noticeable between 0 and 14 DAH for both enzyme ratios and histological features (i.e. IYS and DGD). The differences in enzymatic activities and ratios disappeared during the postembryonic and the juvenile-adult phases (i.e. between 14 and 35 DAH) in experimental standardized rearing due to the fact that all batches received the same food and due to the acquisition of similar digestive performances (i.e. a stabilization phase was observed in enzyme activities, in CL and NBC of digestive cells). When integrating the biological and physiological information (i.e. age, weight, enzyme activities, enzyme ratios and histological features) with the multivariate analysis, only the Linear Discriminatory Analysis applied on new hatched juveniles (i.e. 0 DAH) allowed the observation of clusters by origin sites. The Principal Component Analysis applied on the whole rearing period (i.e. 0 to $35 \mathrm{DAH}$ ) showed no site related clustering and this is due to the standardization of rearing conditions during the experiment. The origin site influence (i.e. the maternal yolk deposit and the incubation conditions) was mainly observable on new hatched juveniles and soon diminished after experimental interference.

\subsubsection{Indicators applied to aquaculture optimization}

The introduction of $S$. officinalis as a new species for aquaculture is a challenging question that researchers have been working on for several years now (Koueta and Boucaud-Camou 1999; Koueta et al. 2000; Perrin et al. 2004;

Domingues and Márquez 2010; Sykes et al. 2013). The establishment of the best rearing conditions and the setting up of a more efficient and inexpensive diet for industrial production of this species are still being explored. However, recent studies have underlined the need to develop physiological tools to allow accurate description of growth performance when testing different diets or different rearing conditions (Sykes et al. 2013). Several indices have been used to describe growth performance in cephalopods, such as biochemical indices for somatic growth (e.g. ARN/ADN and protein ratio) or enzyme activities (e.g. Aspartate transcarbamylase, total proteolytic activity, proteases) in relation to 
instantaneous growth rate (Clarke et al. 1989; Pierce et al. 1999; Koueta et al. 2000; Moltschaniwskyj and Jackson 2000; Villanueva et al. 2002; Roark et al. 2009; Rosas et al. 2011). Among these indices, the influence of digestive enzymes activities have been suggested as determinant for growth performance description (Sykes et al. 2013).

A delay in the digestive system maturation is noticeable between 2010 and 2011. The growth rate was lower in 2011, with mean juvenile weights at $35 \mathrm{DAH}$ around $1.5 \mathrm{~g}$ while it reached $2 \mathrm{~g}$ in 2010 (Fig. 3). The discrepancy between the two years resulted from a delay in the physiological maturation of the digestive system. The decrease in intracellular acid activities (i.e. ACP and cathepsin activities) was lower in 2011 during the post-embryonic to juvenile-adult digestion transition compared to 2010 (Fig. S1). In 2011, the stabilization phase for cathepsin activity was observed starting from $28 \mathrm{DAH}$ and the ACP decrease was seen up to $35 \mathrm{DAH}$ whereas in $2010 \mathrm{ACP}$ and cathepsin stabilized as soon as 21 DAH. Perrin et al. (2004) also noticed that a faster decrease of ACP activity was a sign of a faster maturation of the digestive system. The evolution of ACP and cathepsin activities was consistent with these author's description when comparing juveniles' growth between 2010 and 2011. Trypsin and ALP activities were stabilized from 14 DAH. However, in 2011 the trypsin activity was very variable compared to 2010 (Fig. S1). This last observation could be an indicator of a lower maturation of the digestive system inducing a lower growth rate. Lemieux et al. (1999) worked on a large number of digestive enzymes including trypsin in cod Gadus morhua and this enzyme was described as the only measured one that could be suspected to potentially limit growth rate. In carnivorous species such as cuttlefish, trypsin activity is expected to play a major role in protein digestion (Vonk and Western 1984). High variability in its activity could thus indicate a lower efficiency of extracellular digestion of proteins, which limits the growth rate.

Enzyme activities (i.e. Cathepsin, ACP, ALP and trypsin) were shown to be good markers of juvenile growth performance during early DAH. Nevertheless, when investigating enzyme ratios, integrated, stronger and simplified information is being captured efficiently describing the changes in growth performance. This is particularly noticeable with ALP/ACP ratio. ALP/ACP ratio showed a decrease in the slope of its linear correlation with juvenile growth in 2011 compared to 2010 (i.e. the increase in ALP/ACP ratio between 0 and 35 DAH was faster in 2010 compared to 2011). The ALP/ACP slope decrease reflected the decrease in juveniles' growth performance between the two years. Thus, this ratio is highly relevant to compare growth performance. As for the trypsin/cathepsin ratio, the differences in ratio profiles between 2010 and 2011 were highly influenced by the changes in trypsin activity profiles from one year to the other.

\section{Conclusion}


This study has led to the development of new indicators (i.e. ALP/ACP and trypsin/cathepsin ratios) for the description of digestive gland maturation in Sepia officinalis L. during early-life stages. The use of enzyme ratios allowed a more accurate description of the shift occurring between acid and alkaline digestive enzyme activities during the first month post hatching in cuttlefish juveniles. These indicators were highly correlated with juvenile weight increase and were also correlated with digestive gland maturing features (i.e. mean number of digestive 'balls'/ cell and digestive cell length). This approach is very promising as it gives information on the digestive system maturation with simple tools.

The work undertaken in this study allowed updating knowledge of the main transitional process during digestive gland maturation in S. officinalis L. early-life stages. Cathepsin and ACP activities (i.e. intracellular acidic enzymes) revealed an increasing profile up to 7 DAH before a new decrease before finally stabilizing. While trypsin and ALP activities (i.e. extracellular alkaline enzymes) increased from hatching until 14DAH and then stabilized until 35 DAH. The appearance of well-developed digestive gland cells and plenty of "balls" between 21 and 35 DAH demonstrated that $S$. officinalis reached its digestive maturity when the enzyme activity was stable. However, ALP/ACP ratio has permitted to describe that fine adjustments between intracellular and extracellular digestion still occur at least up to 28 DAH. The relevance of the enzyme ratios as ecological indicators was also demonstrated. The enzyme ratios were inversely correlated to yolk content (IYS) in new hatching juveniles with low values reflecting a high yolk content. This gave an advantage in growth performance for juveniles during the first transition period (i.e. from embryonic to post-embryonic transition). Inversely, higher enzyme ratio values were correlated to a faster digestive gland development (DGD) thus giving it the advantage in the second transitional period (i.e. from post-embryonic to juvenile-adult transition). The enzyme ratios allowed the distinction of two groups of juveniles by reflecting their IYS content and DGD. Combining enzymatic ratio with other tools, such as isotope analysis, should be used in future work to relate the cuttlefish recruitment from coastal spawning sites to juveniles' physiological performance. Finally, a comparison between the two years of study (i.e. 2010 and 2011) revealed the possibility to use enzyme ratios, with mainly the ALP/ACP ratio, as good markers to describe juvenile growth performance. 


\section{Compliance with Ethical Standards}

Conflict of interest The authors declare that they have no conflict of interest.

Ethical approval All procedures performed in this study involving animals were in accordance with the ethical standards of the institution or practice at which the study was conducted. The present study does not contain any experiments carried out by its authors on human participants.

\section{References}

Aguila J, Cuzon G, Pascual C, Domingues PM, Gaxiola G, Sánchez A, Maldonado T, Rosas C (2007) The effects of fish hydrolysate (CPSP) level on Octopus maya (Voss and Solis) diet: Digestive enzyme activity, blood metabolites, and energy balance. Aquaculture. 273: 641-655. doi:10.1016/j.aquaculture.2007.07.010

Balti R, Hmidet N, Jellouli K, Nedjar-Arroume N, Guillochon D, Nasri M (2010) Cathepsin D from the hepatopancreas of the cuttlefish (Sepia officinalis): purification and characterization. J Agr Food Chem 58:10623-30. doi: $10.1021 / j f 102233 d$

Bergeron JP, Koueta N, Massé J (2013) Interannual fluctuations in spring pelagic ecosystem productivity in the Bay of Biscay (northeast Atlantic) measured by mesozooplankton aspartate transcarbamylase activity and relationships with anchovy population dynamics. Fish Res 143: 184-190. doi: 10.1016/j.fishres.2013.02.006

Bloor ISM (2016) The current and changing role of physico-chemical factors and cues in the embryonic and early life stage development of the common cuttlefish (Sepia officinalis). Life Environ 66(1) 81-95.

Bloor ISM, Attrill MJ, Jackson EL (2013) A review of the factors influencing spawning, early life stage survival and recruitment variability in the common cuttlefish (Sepia officinalis). Adv Mar Biol 65: 1-65. doi: 10.1016/B978-0-12410498-3.00001-X

Boletzky SV (1975) A contribution to the study of yolk absorption in the Cephalopoda. Z Morphol Tiere 80: 229-246. doi: $10.1007 / \mathrm{BF} 00285654$

Boletzky SV (1989) Elevage de céphalopodes en aquarium : acquis récents. Bull Soc Zool Fr 114(4): 57-66.

Bonete MJ, Manjon A, LIorca F, Iborra JL (1984) Acid proteinase activity in Fish - Comparative study of extraction of cathepsins B and D from Mujil auratus. Comp Biochem Physiol B 78(1): 203-206

Boucaud-Camou E (1973) Etude de l'appareil digestif de Sepia officinalis L. (Mollusque Céphalopode). Essai d'analyse expérimentale des phénomènes digestifs. Thesis, University of Caen

Boucaud-Camou E (1974) Localisation d'activités enzymatiques impliquées dans la digestion chez Sepia officinalis L. Arch Zool Exp Gen 115: 5-27 
613

614

615

616

617

618

619

620

621

622

623

624

625

626

627

628

629

630

631

632

633

634

635

636

637

638

639

640

641

642

Boucaud-Camou E (1982) Localisation of some hydrolytic enzymes in digestive organs of juvenile Sepia officinalis L.

(Mollusca, Cephalopoda). Malacol 22: 685-690

Boucaud-Camou E, Boismery J (1991) The migrations of the cuttlefish (Sepia officinalis L.) in the English Channel. In

“The Cuttelfish". Centre de publication de l'Université de Caen, France, pp 179-189

Boucaud-Camou E, Boucher-Rodoni R (1983) Feeding and digestion in cephalopods. In: Saleuddin ASM and Wilbur KM (eds) The Mollusca, Vol 5, Physiology Part 2. Academic Press, New York, pp 149-187

Boucaud-Camou E, Roper CFE (1995) Digestive enzymes in paralarval cephalopods. Bull Mar Sci 57: 313-327

Boucaud-Camou E, Yim M (1980) Fine structure and function of the digestive cell of Sepia officinalis (Mollusca:

Cephalopoda). J Zool 191: 89-105. doi: 10.1111/j.1469-7998.1980.tb01451.x

Boucaud-Camou E, Yim M, Tresgot A (1985) Feeding and digestion of young Sepia officinalis L. (Mollusca:

Cephalopoda) during post-hatching development. In: Mangold K and Boletzky SV (eds) Biology and distribution of Early Juvenile Cephalopods. Vie Milieu 35: 263-266

Bouchaud O (1991) Energy consumption of the cuttlefish Sepia officinalis L. (Mollusca: Cephalopoda) during embryonic development, preliminary results. Bull Mar Sci 49(1-2): 333-340

Bouchaud O, Daguzan J (1989) Etude du développement de l'œuf de Sepia officinalis L. (Céphalopode, Sepiidae) en conditions expérimentales. Haliotis 19: 189-200

Boucher-Rodoni R (1981) Etude de la glande digestive de deux céphalopodes, au cours du cycle de vie. Thesis, University of Paris-Sud

Boucher-Rodoni R, Boucaud-Camou E, Mangold K (1987) Feeding and digestion. In: Boyle PR (ed) Cephalopod Life Cycles Vol 2, Academic Press, London, pp 85-108

Bradford MM (1976) A rapid sensitive method for quantification of microgram quantities of protein utilizing the principle of protein-dye binding. Anal Biochem 72: 248-254. doi:10.1016/0003-2697(76)90527-3

Budelmann B, Schipp R, Boletzky SV (1997) Cephalopoda. In: Harrison FW, Kohn AJ (Eds.) Microscopic anatomy of invertebrates, Vol. 6A. Wiley-Liss, Inc, New York, pp 119-414

Cahu CL, Zambonino-Infante JL (1995) Maturation of the pancreatic and intestinal digestive functions in sea bass (Dicentrarchus labrax): effect of weaning with different protein sources. Fish Physiol Biochem 14: 431-437. doi:

\subsection{7/BF00004343}

Chouvelon T, Spitz J, Cherel Y, Caurant F, Sirmel R, Mendez-Fernandez P, Bustamente P (2011) Inter-specific and ontogenic differences in $\delta^{13} \mathrm{C}$ and $\delta^{15} \mathrm{~N}$ values and $\mathrm{Hg}$ and $\mathrm{Cd}$ concentrations in cephalopods. Mar Ecol Prog Ser 433: 107-120. doi:10.3354/meps09159 
643

644

645

646

647

648

649

650

651

652

653

654

655

656

657

658

659

660

661

662

663

664

665

666

667

668

669

670

Clarke A, Rodhouse PG, Holmes LJ, Pascoe PL, 1989. Growth rate and nucleic acid ration in cultured cuttlefish Sepia officinalis (Mollusca Cephalopoda). J Exp Mar Biol Ecol 133, 229-240. doi:10.1016/0022-0981(89)90047-6

Costa PM, Rodrigo AP, Costa MH (2014) Microstructural and histochemical advances on the digestive gland of the common cuttlefish, Sepia officinalis L. Zoomorphology 133: 59-69. doi: 10.1007/s00435-013-0201-8

De Fraipont M, Clobert J, John-Alder H, Meylan S (2000) Increased pre-natal maternal corticosterone promotes philopatry of offspring in common lizards Lacerta vivipara. J Anim Ecol 69: 404-413. doi: 10.1046/j.1365-

2656.2000.00405.x

Domingues P, Márquez L. (2010) Effects of culture density and bottom area on growth and survival of the cuttlefish Sepia officinalis (Linnaeus, 1758). Aquacult Int 18:361-369. doi: 10.1007/s10499-009-9249-3

Dunn MR (1999) Aspects of the stock dynamics and exploitation of cuttlefish, Sepia officinalis (Linnaeus, 1758), in the English Channel. Fish Res 40: 277-293. doi: 10.1016/S0165-7836(98)00223-9

Eising CM, Eikenaar C, Schwabl H, Groothuis TG (2001) Maternal androgens in black-headed gull (Larus ridibundus) eggs: consequences for chick development. Proc R Soc B 268: 839-846. doi: 10.1098/rspb.2001.1594

European Parliament, Council of the European Union, 2010. Directive 2010/63/EU of the European Parliament and of the Council of 22 September 2010 on the Protection of Animals Used for Scientific Purposes. Council of Europe,

Strasbourg

Fabris C, Smirne C, Toniutto P, Colletta C, Rapetti R, Minisini R, Falleti E, Pirisi M (2006) Assessment of liver fibrosis progression in patients with chronic hepatitis $\mathrm{C}$ and normal alanine aminotransferase values: the role of AST to the platelet ratio index. Clin Biochem 39: 339-343. doi:10.1016/j.clinbiochem.2006.01.011

Fagotto F (1990) Yolk degradation in tick eggs. Evidence that cathepsin L-Like proteinase is stored as a latent, acidactivable proenzyme. Arch Insect Biochem Physiol 14: 237-252. doi: 10.1002/arch.940140404

Fagotto F (1991) Yolk degradation in tick eggs. Developmentally regulated acidification of the yolk spheres. Dev Growth Differ 33: 57-66. doi: 10.1111/j.1440-169X.1991.00057.x

Fiorito G, Affuso A, Basil J, et al (2015) Guidelines for the Care and Welfare of Cephalopods in Research -A consensus based on an initiative by CephRes, FELASA and the Boyd Group. Lab Anim 49:1-90. doi: $10.1177 / 0023677215580006$

Fox J, Weisberg S (2011) An R Companion to Applied Regression, Second Edition. Sage, Thousand Oaks, CA http://socserv.socsci.mcmaster.ca/jfox/ Books/Companion 
671

672

673

674

675

676

677

678

679

680

681

682

683

684

685

686

687

688

689

690

691

692

693

694

695

696

697

698

699

Fukuda Y, Miura S, Tsuchiya Y et al. (2011) Lower frequency of non-target lesion intervention in post-successful percutaneous coronary intervention patients with an LDL to HDL cholesterol ratio below 1.5. Int J Cardiol 149: 120122. doi: 10.1016/j.ijcard.2011.01.088

Gabe M (1968) Techniques histologiques. Masson et Cie, Paris

Gárdenas-López JL, Haard NF (2009) Identification of a cysteine proteinase from Jumbo squid (Dosidicus gigas) hepatopancreas as cathepsin L. Food Chem 112(2): 442 - 447. doi:10.1016/j.foodchem.2008.05.100

Georgopoulou U, Sire MF, Vernier JM (1985) Macromolecular absorption of proteins by epithelial cells of the posterior intestinal segment and their intracellular digestion in the rainbow trout. Ultrastructural and biochemical study. Biol Cell 53: $269-282$

Gildberg A (1988) Aspartic proteinases in fishes and aquatic invertebrates. Comp Biochem Phys B, 91(3): 425-435. doi:10.1016/0305-0491(88)90002-8

Govoni JJ, Boehlert GW, Watanabe Y (1986) The physiology of digestion in fish larvae. Environ Biol Fishes 16: 59-77. doi: $10.1007 / \mathrm{BF} 00005160$

Gras M, Safi G, Lebredonchel H, Quinquis J, Foucher E, Koueta N, Robin JP (2016) Stock structure of the English Channel common cuttlefish Sepia officinalis (Linnaeus, 1758) during the reproduction period. J Mar Biol Assoc UK 167-176. doi: $10.1017 / \mathrm{s} 0025315415001162$

Hervé M (2012) RVAideMemoire: Diverse Basic Statistical and Graphical Functions. R package version 0.9-11. http://CRAN.R-project.org/package=RVAideMemoire

Jackson GD, Bustamante P, Cherel Y, Fulton EA, Grist EPM, Jackson CH, Nichols PD, Pethybridge H, Philips K, Ward RD, Xavier JC (2007) Applying new tools to cephalopod trophic dynamics and ecology: perspectives from the Southern Ocean Cephalopod Workshop, February 2-3, 2006. Rev Fish Biol Fisheries 17: 79-99. doi: 10.1007/s11160007-9055-9

Jellouli K, Bougatef A, Daassi D, Balti R, Barkia A, Nasri M (2009) New alkaline trypsin from the intestine of Grey triggerfish (Balistes capriscus) with high activity at low temperature: purification and characterisation. Food Chem 116 : 644-650. doi:10.1016/j.foodchem.2009.02.087

Jereb P, Allcock AL, Lefkaditou E, Piatkowski U, Hastie LC, Pierce GJ (2015) Cephalopod biology and fisheries in Europe: II. Species Accounts. ICES Coop Res Rep No 325

Kolodziejska I, Sikorski ZE (1996) The digestive proteases of marine fish and invertebrates. Bull Sea Fish Inst Gdynia 137: 51-56. 
Koueta N, Boucau-Camou E (1999) Food intake and growth in reared early juvenile cuttlefish Sepia officinalis L. (Mollusca Cephalopoda). J Exp Mar Biol Ecol 240: 93-109. doi: 10.1016/S0022-0981(99)00054-4

Koueta N, Castro BG, Boucaud-Camou E (2000) Biochemical indices for instantaneous growth estimation in young cephalopod Sepia officinalis L. ICES J Mar Sci 57: 1-7. doi: 10.1006/jmsc.1999.0503

Koueta N, Castro B G, Boucaud-Camou E (2000) Biochemical indices for instantaneous growth estimation in young cephalopod Sepia officinalis L.

Lacoue-Labarthe T, Le Bihan E, Borg D, Koueta N, Bustamante P (2010) Acid phosphatase and cathepsin activity in cuttlefish (Sepia officinalis) eggs: the effects of Ag, Cd, and Cu exposure. ICES J Mar Sci 67(7): 1517-1523. doi:10.1093/icesjms/fsq044

Lazo JP, Mendoza R, Holt GJ, Aguilera C, Arnold CR (2007) Characterization of digestive enzymes during larval development of red drum (Sciaenops ocellatus). Aquaculture 265: 194-205. doi: 10.1016/j.aquaculture.2007.01.043 Le Bihan E, Perrin A, Koueta N (2006a) Influence of diet peptide content on survival, growth and digestive enzymes activities of juvenile cuttlefish Sepia officinalis. Life Environ 56: 139-145

Le Bihan E, Zatylny C, Perrin A, Koueta N (2006b) Post-mortem changes in viscera of cuttlefish Sepia officinalis L. during storage at two different temperatures. Food Chem 98: 39-51

Lemieux H, Blier P, Dutil JD (1999) Do digestive enzymes set a physiological limit on growth rate and food conversion efficiency in the atlantic cod (Gadus morhua). Fish Physiol Biochem 20: 293-303. doi: 10.1023/A:1007791019523 Le Pabic C, Caplat C, Lehodey JP, Dallas L, Koueta N (2015) Physiological perturbations in juvenile cuttlefish Sepia officinalis induced by subchronic exposure to dissolved zinc. Mar Pollut Bull 95: 678-687. doi: 10.1016/j.marpolbul.2015.02.018

Linnaeus C (1758) Systema Naturae per regna tria naturae, secundum classes, ordines, genera, species, cum characteribus, differentiis, synonymis, locis. Editio decima, reformata. Laurentius Salvius: Holmiae.

Lopez-Peraza DJ, Hernandez-Rodriguez M, Baron-Sevilla B (2014) Ontogeny of the digestive system of the Octopus bimaculatus paralarvae (Verril, 1883). Springerplus 3:22. doi: 10.1186/2193-1801-3-22

Lourenço S, Narciso L, Gonzalez AF, Pereira J, Auborg S, Xavier JC (2014) Does the trophic habitat influence the biochemical quality of the gonad of Octopus vulgaris? Stable isotopes and lipid class contents as bio-indicators of different life-cycle strategies. Hydrobiologia 725(1): 33 - 46. doi: 10.1007/s10750-013-1717-0 Martínez R, López-Ripoll E, Avila-Poveda O, Santos-Ricalde R, Mascaró M, Rosas C (2011) Cytological ontogeny of the digestive gland in post-hatching Octopus maya, and cytological background of digestion in juveniles. Aquat Biol 11: 249-261. doi: 10.3354/ab00305 
Mazorra MT, Rubio JA, Blasco J (2002) Acid and alkaline phosphatase activities in the clam Scrobicularia plana: kinetic characteristics and effects of heavy metals. Comp Biochem Phy B 131: 241-249. doi: 10.1016/S10964959(01)00502-4

Moguel C, Mascaró M, Avila-Poveda O, Caamal-Monsreal C, Sanchez A, Pascual C, Rosas C (2010) Morphological, physiological and behavioral changes during post-hatching development of Octopus maya (Mollusca: Cephalopoda) with special focus on the digestive system. Aquat Biol 9: 35-48. doi: 10.3354/ab00234 Moltschaniwskyj NA, Jackson GD (2000) Growth and tissue composition as a function of feeding history in juvenile cephalopods. J Exp Mar Biol Ecol 253: 229-241. doi: 10.1016/s0022-0981(00)00257-4 Morishita T (1972) On the existence of cathepsins A, B and C in octopus liver. Bull Jpn Soc Sci Fish 38: $1057-1060$ Moyano FJ, Diaz M, Alarcon FJ, Sarasquete MC (1996) Characterization of digestive enzyme activity during larval development of gilthead seabream (Sparus aurata). Fish Physiol Biochem 2: 121-130. doi: 10.1007/BF01875591 O’Dor RK, Webber DM (1986) The constraints on cephalopods: why squid aren't fish. Can J Zool 64: 1591-1605. doi: $10.1139 / \mathrm{z} 86-241$

O’Dor RK, Wells MJ (1975) Control of yolk protein synthesis by Octopus gonadotropin in vivo and in vitro (effects of Octopus gonadotropin). Gen Comp Endocr 27: 129-135. doi:10.1016/0016-6480(75)90226-9

Öztürk G, Akbulut KG, Güney Ş, Acuna-Castroviejo D (2012) Age-related changes in the rat brain mitochondrial antioxidative enzyme ratios: modulation by melatonin. Exp Gerontol 47: 706-711. doi: 10.1016/j.exger.2012.06.011 Pereda SV, Uriarte I, Cabrera JC (2009) Effect of diet and paralarval development on digestive enzyme activity in the cephalopod Robsonella fontaniana. Mar Biol 156: 2121-2128. doi: 10.1007/s00227-009-1242-x

Perrin A, Le Bihan E, Koueta N (2004) Experimental study of enriched frozen diet on digestive enzymes and growth of juvenile cuttlefish Sepia officinalis L. (Mollusca Cephalopoda). J Exp Mar Biol Ecol 311: 267-285. doi: 10.1016/j.jembe.2004.05.012

Pierce GJ, Key LN, Boyle PR, Siegert KJ, Gonc JM, Porteiro FM, Martins HR (1999) RNA concentration and the RNA to protein ratio in cephalopod tissues: sources of variation and relationship with growth rate. J Exp Mar Biol Ecol 237: 185-201. doi:10.1016/S0022-0981(99)00008-8

Pierce GJ, Valavanis VD, Guerra A et al. (2008) A review of cephalopod-environment interactions in European Seas. Hydrobiologia 612: 49-70. doi: 10.1007/s10750-008-9489-7

Principato GB, Cristina-Aisa M, Biagoni M, Giovannini E (1982) Partial purification and characterization of an alkaline phosphatase in Helix nemoralis and in Octopus vulgaris. Comp Biochem Phy B 72(2): 325-328. doi: 10.1016/03050491(82)90055-4 
R Core Team (2012) R: A Language and Environment for Statistical Computing. R Foundation for Statistical Computing, Vienna, Austria, ISBN 3-900051-07-0 http://www.R-project.org/

Roark AM, Bjorndal KA, Bolten AB, Leeuwenburgh C (2009) Biochemical indices as correlates of recent growth in juvenile green turtles (Chelonia mydas). J Exp Mar Biol Ecol 376: 59-67. doi: 10.1016/j.jembe.2009.06.004

Rosas C, Sánchez A, Pascual C, Aguila J, Maldonado T, Domingues P (2011) Effects of two dietary protein levels on energy balance and digestive capacity of Octopus maya. Aquacult Int 19: 165-180. doi: 10.1007/s10499-010-9350-7 Segers FHID, Taborsky B (2010) Egg size and food abundance interactively affect juvenile growth and behaviour. Funct Ecol 25: 166-176. doi: 10.1111/j.1365-2435.2010.01790.x

Semmens JM (2002) Changes in the digestive gland of the loliginid squid Sepioteuthis lessoniana (Lesson 1830) associated with feeding. J Exp Mar Biol Ecol 274: 19-39. doi:10.1016/S0022-0981(02)00165-X Semmens JM, Pecl GT, Gillanders BM, Waluda CM, Shea EK, Jouffre D, Ichii T, Zumholz K, Katugin ON, Leporati SC, Shaw PW (2007) Approaches to resolving cephalopod movement and migration patterns. Rev Fish Biol Fisher 17: 401-423. doi: 10.1007/s11160-007-9048-8

Shin WG, Park SH, Jang MK, Hahn TH, Kim JB, Lee MS, Kim DJ, Jun S-Y, Park CK (2008) Aspartate aminotransferase to platelet ratio index (APRI) can predict liver fibrosis in chronic hepatitis B. Dig Liver Dis 40: 267274. doi:10.1016/j.dld.2007.10.011

Solorzano Y, Viana MT, López LM, Correa JG, True CC, Rosas C (2009) Response of newly hatched Octopus bimaculoides fed enriched Artemia salina: Growth performance, ontogeny of the digestive enzyme and tissue amino acid content. Aquaculture 289: 84-90. doi:10.1016/j.aquaculture.2008.12.036

Soška V, Jarkovský J, Ravčuková B, Tichý L, Fajkusová L, Freiberger T (2012) The logarithm of the triglyceride/HDLcholesterol ratio is related to the history of cardiovascular disease in patients with familial hypercholesterolemia. Clin Biochem 45: 96-100. doi: 10.1016/j.clinbiochem.2011.11.001

Swift K, Johnston D, Moltschaniwskyj N (2005) The digestive gland of the Southern Dumpling Squid (Euprymna tasmanica): structure and function. J Exp Mar Biol Ecol 315, 177-186. doi: 10.1016/j.jembe.2004.09.017

Sykes A V, Gonçalves R A, Andrade J P (2013) Early weaning of cuttlefish (Sepia officinalis, L.) with frozen grass shrimp (Palaemonetes varians) from the first day after hatching. Aquacult Res 44:1815-1823. doi: 10.1111/j.13652109.2012.03186.x

Tsunematsu H, Nishimura H, Mizusaki K, Makisumi S (1985) Kinetics of hydrolysis of amide and anilide substrates of p-Guanidino-L-Phenylalanine by bovine and porcine trypsins. J Biochem 97: 617-623. 
Uller T, Astheimer L, Olsson M (2007) Consequences of maternal yolk testosterone for offspring development and survival: experimental test in a lizard. Funct Ecol 21: 544-551. doi: 10.1111/j.1365-2435.2007.01264.x

Umezawa H (1982) Low-molecular-weight enzyme inhibitors of microbial origin. Annu. Rev. Microbiol. 36 , 75-99. doi: 10.1146/annurev.mi.36.100182.000451

Vecchione M (1987) Juvenile ecology. In: Boyle PR (Ed) Cephalopod Life Cycles, Academic Press, London, pp 61-84 Vecchione M, Hand VA (1989) Digestive-gland histology in paralarval squids (Cephalopoda: Loliginidae). Fish Bull 87: $995-1000$

Vidal EAG, Dimarco FP, Wormuth JH, Lee PG (2002) Influence of temperature and food availability on survival, growth and yolk utilization in hatchling squid. Bull Mar Sci 71: 915-931

Villanueva R, Koueta N, Riba J, Boucaud-Camou E (2002) Growth and proteolytic activity of Octopus vulgaris paralarvae with different food rations during first feeding, using Artemia nauplii and compound diets. Aquaculture. 205: 269-286. doi:10.1016/S0044-8486(01)00678-0

Vonk HJ, Western JRH (1984) Comparative biochemistry and physiology of enzymatic digestion. Academic Press, London, pp 109-119

Yim M, Boucaud-Camou E (1980) Etude cytologique du développement post-embryonnaire de la glande digestive de Sepia officinalis L. Mollusque Céphalopode. Arch Anat Microsc Morphol Exp 69: 59-79. 


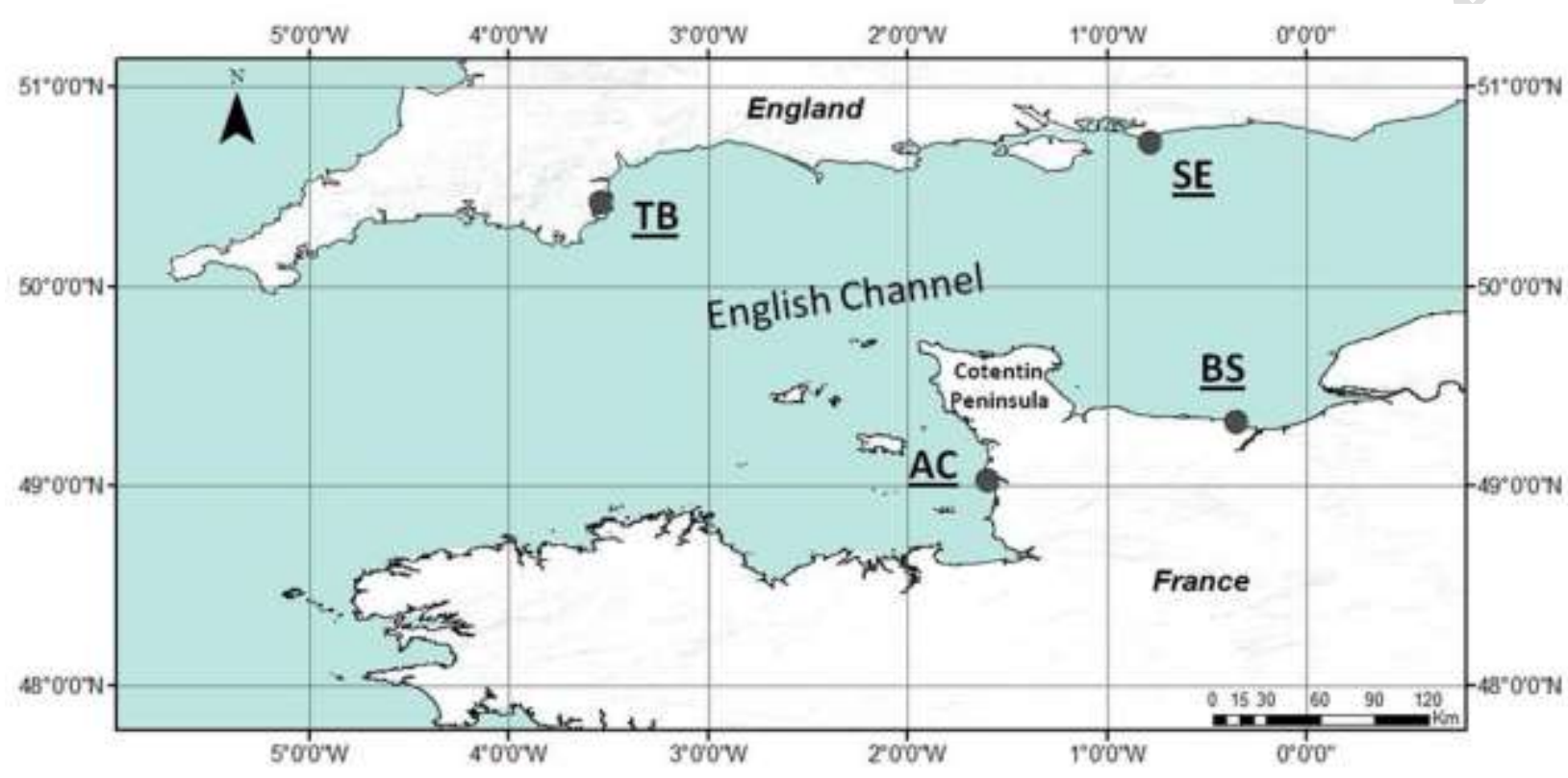

806 Fig. 1 Spawning sites distribution of Sepia officinalis in the English Channel. The monitored spawning sites are: BS (Bay of Seine-FR), AC (Agon Coutainville-FR), TB 807 (Torbay-UK) and SE (Selsey-UK) 

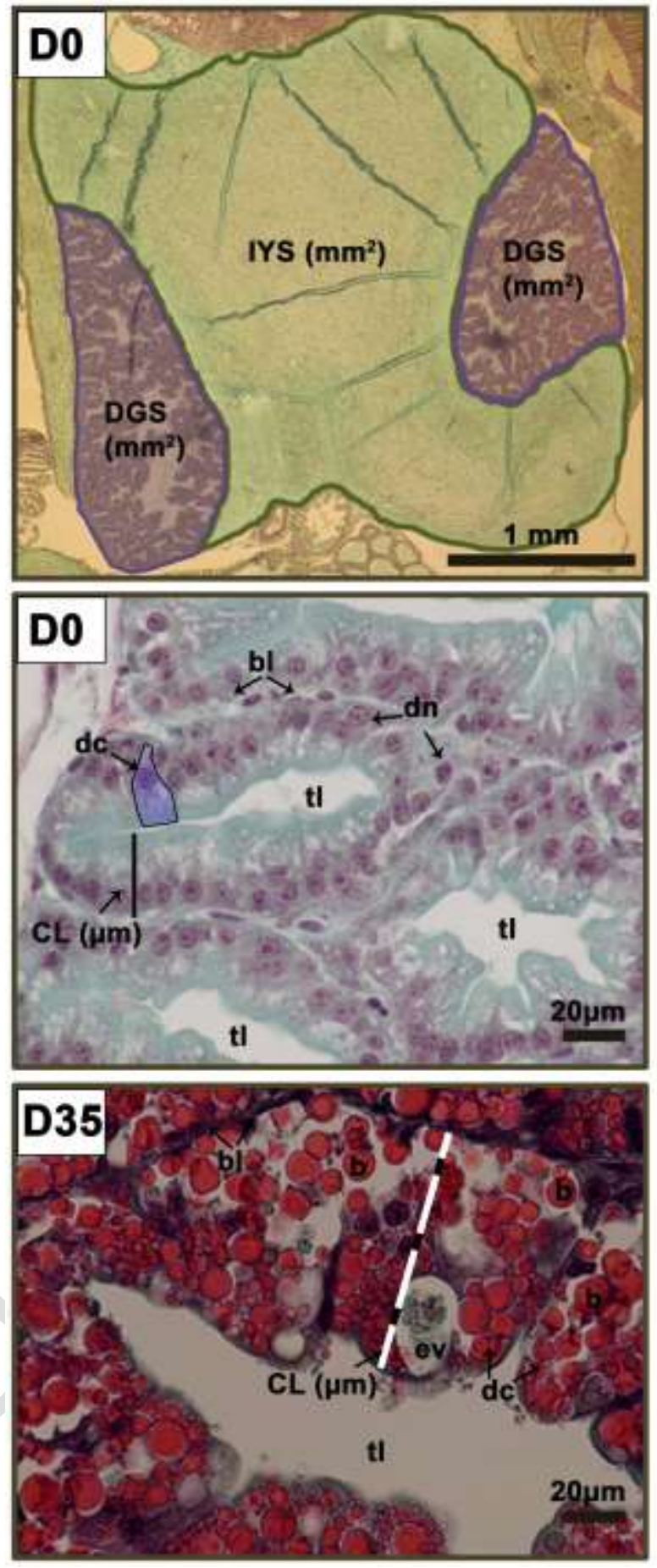

809 Fig. 2 Structural analysis of Sepia officinalis digestive gland at hatching (D0) and 35 days after hatching (D35).

810 b: "balls" (proteinaceous inclusions characteristic of most cephalopods), bl: basal lamina, CL: digestive cell

811 length $(\mu \mathrm{m})$, dc: digestive cell, DGS: digestive gland surface $\left(\mu \mathrm{m}^{2}\right)$, dn: digestive cell nucleus, ev: excretory

812 vacuole, IYS: internal yolk surface $\left(\mu \mathrm{m}^{2}\right)$, tl: tubule's lumen. Histological sections were stained with Prenant-

813 Gabe's trichrome 

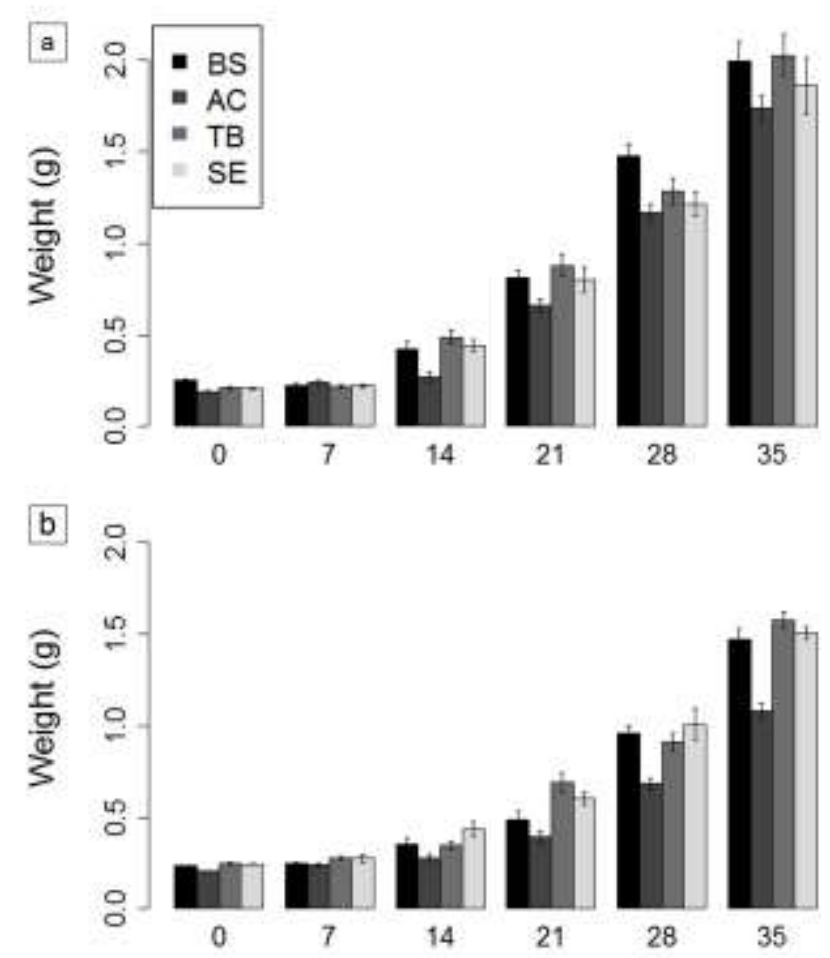

Days after hatching

814

815 Fig. 3 Growth of cuttlefish juveniles Sepia officinalis during their early days after hatching (DAH) in two

816 different years (a: 2010; b: 2011) (see Table S1 for N juveniles/site/DAH values: mean \pm standard error).

817 Cuttlefish hatched from eggs collected from different spawning locations in the English Channel, namely BS:

818 Bay of Seine, AC: Agon Coutainville, TB: Torbay, SE: Selsey.

819
Table 1 Statistical results of a two-ways ANOVA (factors site and age) applied to growth of Sepia officinalis juveniles, as presented in Fig. 3. Cuttlefish hatched from eggs collected from different spawning locations in the English Channel, namely BS: Bay of Seine, AC: Agon Coutainville, TB: Torbay, SE: Selsey.

\begin{tabular}{cccccccc}
\hline \multirow{2}{*}{ year } & site & \multicolumn{7}{c}{ Age (days) } \\
\cline { 3 - 8 } & & $\mathbf{0}$ & $\mathbf{7}$ & $\mathbf{1 4}$ & $\mathbf{2 1}$ & $\mathbf{2 8}$ & $\mathbf{3 5}$ \\
\hline \multirow{4}{*}{2010} & BS & hi & i & ghi & efg & bc & a \\
& AC & i & hi & hi & fgh & cde & ab \\
& TB & i & i & fghi & def & cd & a \\
& SE & i & i & ghi & efg & cde & a \\
\hline \multirow{4}{*}{2011} & BS & fg & fg & efg & def & b & a \\
& AC & g & fg & fg & efg & cd & b \\
& TB & fg & fg & efg & cd & bc & a \\
& SE & fg & fg & defg & de & b & a \\
\hline
\end{tabular}



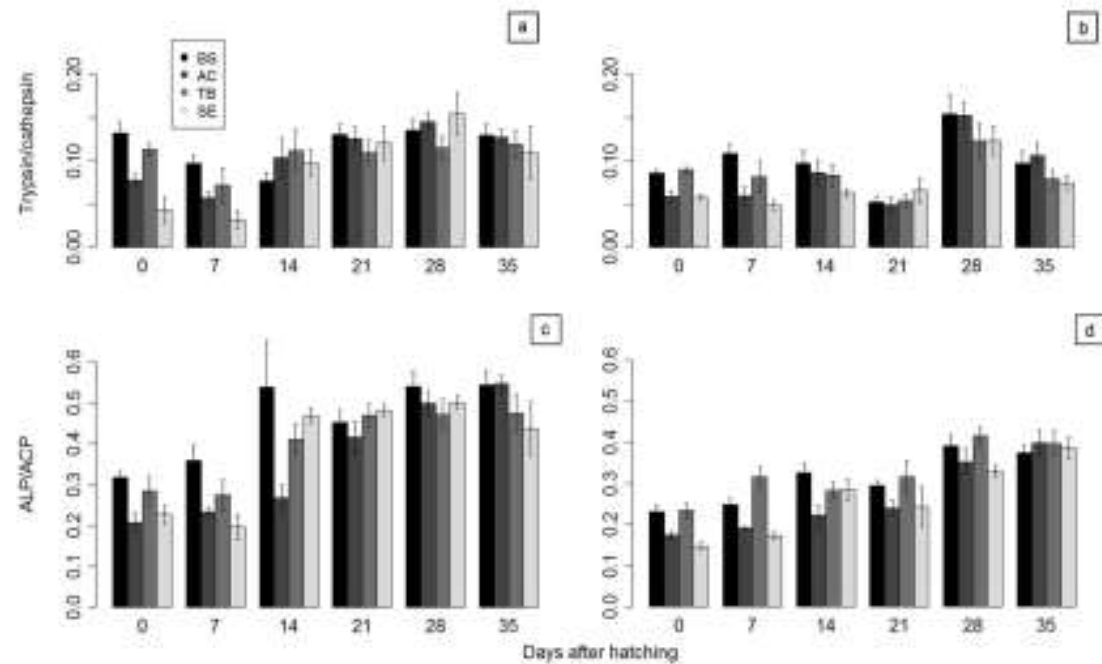

824

Fig. 4 Enzyme ratios' evolution (i.e. trypsin/ cathepsin and alkalin and acid phosphatases, ALP/ACP) in Sepia officinalis juveniles during their early days after hatching (DAH) in 2010 (Barplots a and c) and 2011 (Barplots b and d). $\mathrm{N}=5$ juveniles/site/DAH, values: mean \pm standard error. Cuttlefish hatched from eggs collected from different spawning locations in the English Channel, namely BS: Bay of Seine, AC: Agon Coutainville, TB: Torbay, SE: Selsey.

Table 2 Statistical results of a two-ways ANOVA (factors site and age) applied for enzyme ratios'evolution in Sepia officinalis juveniles presented in Fig. 4. Cuttlefish hatched from eggs collected from different spawning locations in the English Channel, namely BS: Bay of Seine, AC: Agon Coutainville, TB: Torbay, SE: Selsey.

\begin{tabular}{|c|c|c|c|c|c|c|c|c|}
\hline \multirow{2}{*}{ Enzyme ratio } & \multirow{2}{*}{ year } & \multirow{2}{*}{ site } & \multicolumn{6}{|c|}{ Age (days) } \\
\hline & & & 0 & 7 & 14 & 21 & 28 & 35 \\
\hline \multirow{8}{*}{ 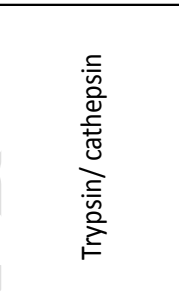 } & \multirow{4}{*}{2010} & BS & $a b c$ & abcd & abcd & $a b c$ & $a b$ & $a b c$ \\
\hline & & $A C$ & abcd & bcd & abcd & $a b c$ & $a b$ & $a b c$ \\
\hline & & TB & abcd & abcd & abcd & abcd & abcd & abcd \\
\hline & & SE & $\mathrm{cd}$ & d & abcd & abcd & $a$ & abcd \\
\hline & \multirow{4}{*}{2011} & BS & $a b$ & $a b$ & $a b$ & $b$ & $a$ & $a b$ \\
\hline & & $A C$ & $\mathrm{~b}$ & $\mathrm{~b}$ & $a b$ & $b$ & a & $a b$ \\
\hline & & $\mathrm{TB}$ & $a b$ & $a b$ & $a b$ & $b$ & $a b$ & $a b$ \\
\hline & & SE & $\mathrm{b}$ & $\mathrm{b}$ & $\mathrm{b}$ & $\mathrm{b}$ & $a b$ & $a b$ \\
\hline \multirow{8}{*}{$\frac{\text { 岀 }}{\frac{\Delta}{2}}$} & \multirow{4}{*}{2010} & BS & bcdefg & abcdefg & 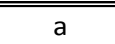 & abcde & $\overline{a b}$ & $\overline{a b}$ \\
\hline & & $A C$ & $\mathrm{fg}$ & efg & defg & abcd & abc & $a b$ \\
\hline & & $\mathrm{TB}$ & cdefg & cdefg & abcdefg & abcd & abcd & abcd \\
\hline & & SE & efg & $\mathrm{g}$ & abcd & abcd & $a b c$ & abcdef \\
\hline & \multirow{4}{*}{2011} & BS & cdef & bcdef & $a b c$ & abcde & $a$ & $a b$ \\
\hline & & $A C$ & ef & def & cdef & bcdef & $a b c$ & $a$ \\
\hline & & $\mathrm{TB}$ & cdef & abcd & abcde & abcd & a & $a$ \\
\hline & & SE & $f$ & ef & abcde & bcdef & $a b c$ & $a$ \\
\hline
\end{tabular}



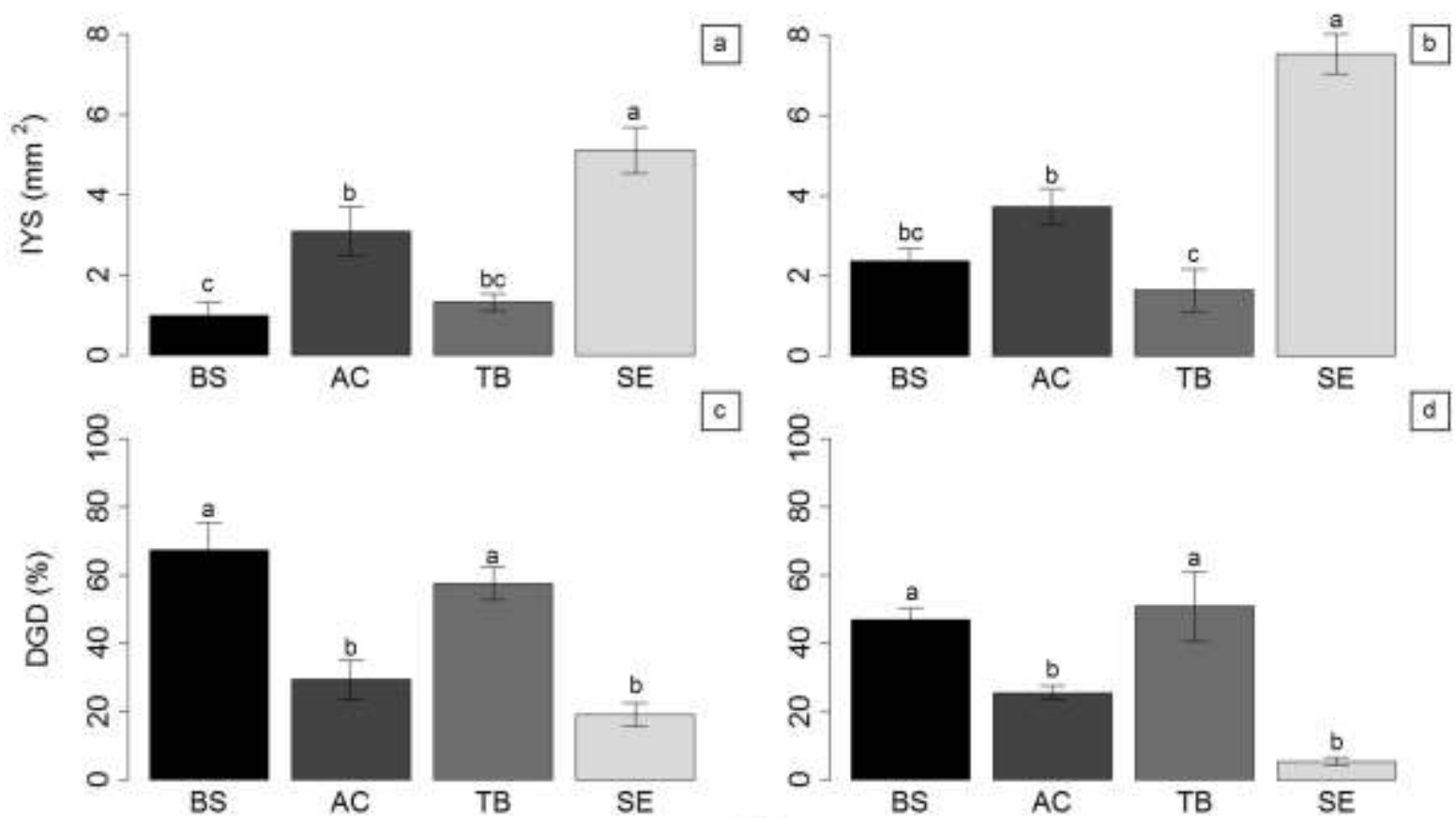

c)

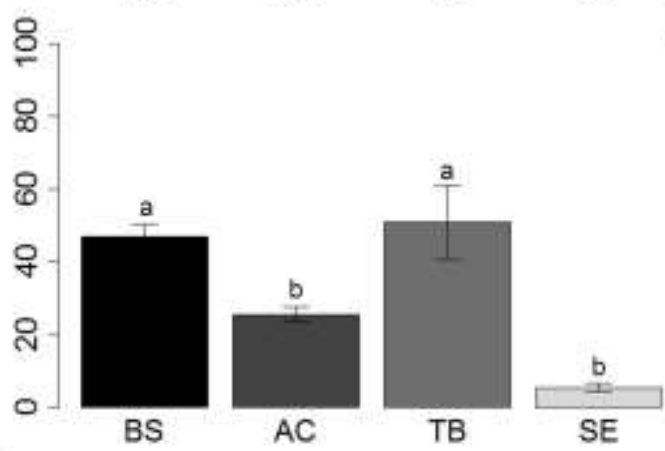

Fig. 5 Sepia officinalis digestive gland characteristics at hatching (0 DAH) in 2010 (Barplots: a and c; n=6) and 2011 (Barplots: $\mathrm{b}$ and $\mathrm{d} ; \mathrm{n}=10$, values: mean \pm standard error). IYS: Internal Yolk Surface $\left(\mathrm{mm}^{2}\right), \mathrm{DGD}=$

Digestive Gland Development (\%).Cuttlefish hatched from eggs collected from different spawning locations in the English Channel, namely BS: Bay of Seine, AC: Agon Coutainville, TB: Torbay, SE: Selsey. Barplots not bearing the same subscript letter are significantly different $(\mathrm{p}<0.05$, one way ANOVA for factor site) 

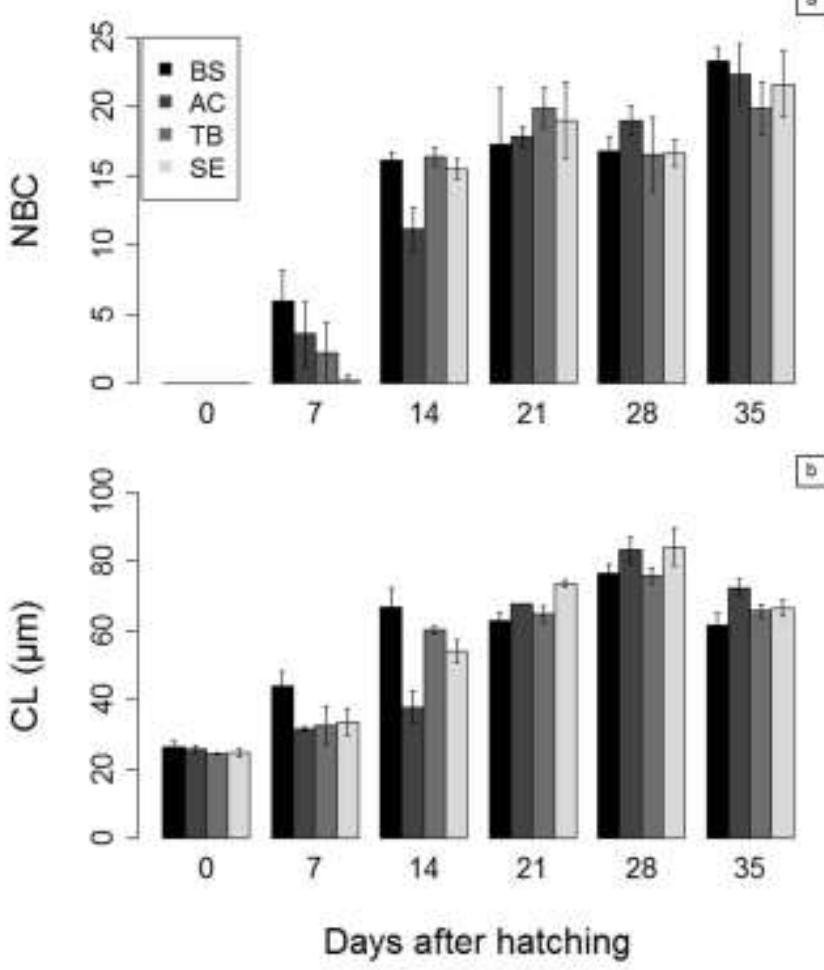

843 Fig. 6 Sepia officinalis mean number of « balls » per cell (NBC, barplot a) and digestive cell length (CL, barplot b) during early post hatching days (35 DAH) $(n=6 /$ site/DAH, values: mean \pm standard error). Cuttlefish hatched from eggs collected in 2010 from different spawning locations in the English Channel, namely BS: Bay of Seine, AC: Agon Coutainville, TB: Torbay, SE: Selsey.

Table 3 Statistical results of a two-ways ANOVA (factors site and age) used to characterize the histological features of Sepia officinalis juveniles, as presented in Fig. 6. NBC: mean number of « balls » per cell; CL: cell length. Cuttlefish hatched from eggs collected from different spawning locations in the English Channel, namely BS: Bay of Seine, AC: Agon Coutainville, TB: Torbay, SE: Selsey.

\begin{tabular}{|c|c|c|c|c|c|c|c|}
\hline \multirow{2}{*}{$\begin{array}{l}\text { Histological } \\
\text { feature }\end{array}$} & \multirow{2}{*}{ site } & \multicolumn{6}{|c|}{ Age (days) } \\
\hline & & 0 & 7 & 14 & 21 & 28 & 35 \\
\hline \multirow{4}{*}{ NBC } & BS & $d$ & bcd & $a b c$ & $a b$ & $a b c$ & $\bar{a}$ \\
\hline & $A C$ & $d$ & $\mathrm{~cd}$ & abcd & $a b$ & $a b$ & a \\
\hline & $\mathrm{TB}$ & $d$ & $d$ & $a b c$ & a & $a b c$ & a \\
\hline & SE & $\mathrm{d}$ & d & $a b c$ & $a b$ & $a b c$ & $a$ \\
\hline \multirow{4}{*}{$\mathrm{CL}$} & BS & $\mathrm{fg}$ & bcdefg & $a b c$ & abcde & $a b$ & abcde \\
\hline & $A C$ & $\mathrm{~g}$ & efg & cdefg & $a b c$ & a & $a b$ \\
\hline & TB & $\mathrm{g}$ & defg & abcdef & abcde & $a b$ & abcde \\
\hline & SE & $\mathrm{g}$ & cdefg & abcdefg & $a b$ & a & abcd \\
\hline
\end{tabular}



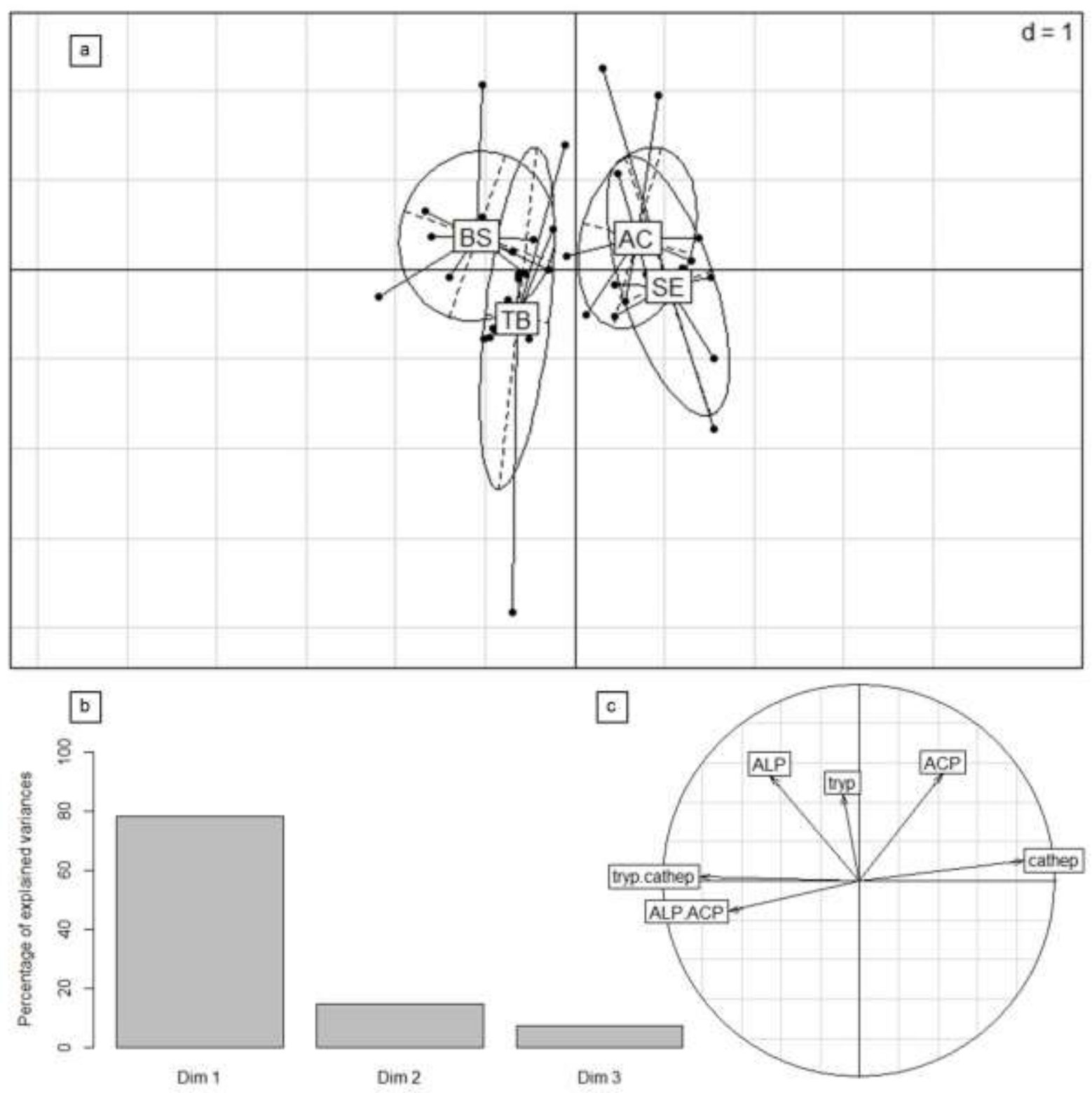

853 Fig. 7 Linear discriminant analysis performed on juveniles cuttlefish at hatching day (0 DAH), sampled in four

854 spawning sites from the English Channel (i.e. BS: Bay of Seine, AC: Agon Coutainville, TB: Torbay, SE: Selsey) in

8552010 and 2011. (a) Plane formed by the first two principal dimensions with the projection of the individual samples; (b)

856 Percentage of explained variances on the first three dimensions; (c) Correlation circle. ACP: acid phosphatase enzyme activity; ALP: alkaline phosphatase enzyme activity; cathep: cathepsin enzyme activity; tryp: trypsin enzyme activity; tryp.cathep and ALP.ACP: enzyme ratios. 

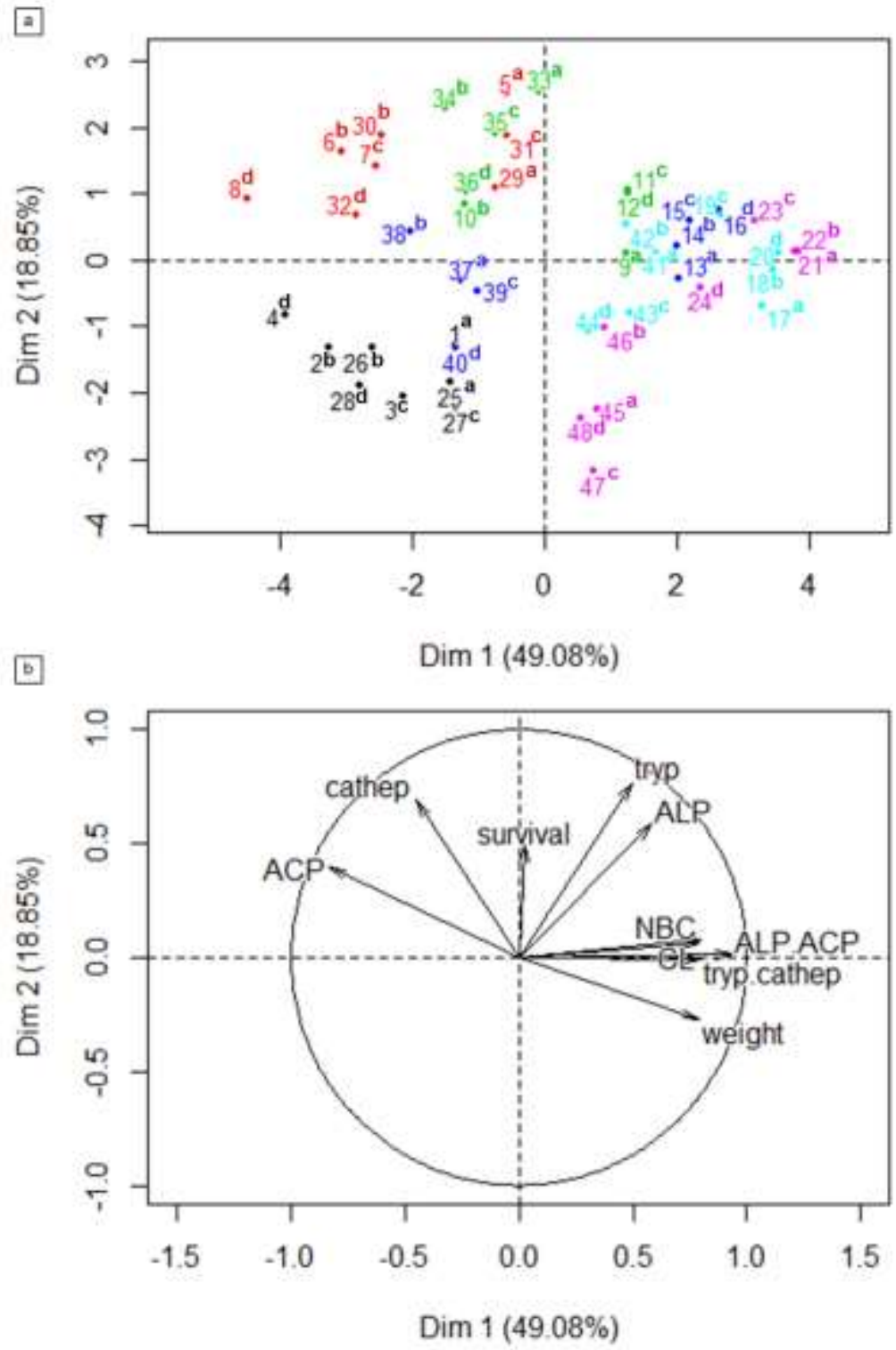

860 Fig. 8 Principal Component Analysis showing the projection on the plane formed by the first two principal dimensions 861 of individual samples (categorized according to cuttlefish age) (a) and the related variables in the correlation circle (b). In plot a, the color code correspond to the cuttlefish age, being respectively 0 DAH (black), 7 DAH (red), 14 DAH

863 (green), $21 \mathrm{DAH}$ (blue), $28 \mathrm{DAH}$ (light-blue) and $35 \mathrm{DAH}$ (purple). Numbers 1 to 24 are for samples of 2010 and numbers 25 to 48 for samples of 2011. The four studied sites are identified by the superscript letters a (BS), b (AC), c

865 (TB) and d (SE).ACP: acid phosphatase enzyme activity; ALP: alkaline phosphatase enzyme activity; cathep: cathepsin enzyme activity; CL: cell length; NBC: mean number of digestive 'balls'/cell; tryp: trypsin enzyme activity; tryp.cathep and ALP.ACP: enzyme ratios. 


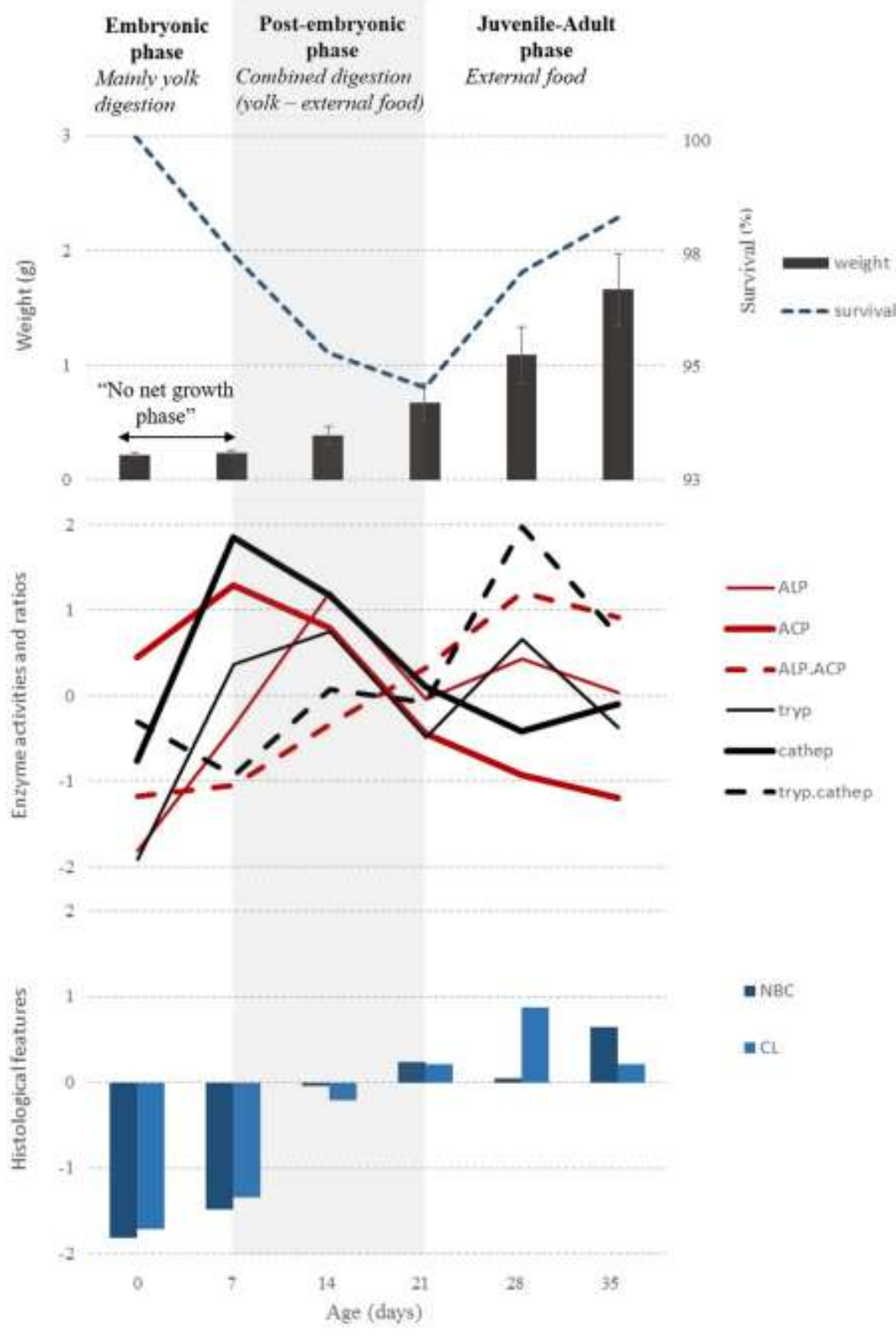

869 Fig. 9 Outline of the main physiological and digestive processes occurring in early post hatching days of Sepia officinalis. ACP: acid phosphatase enzyme activity; ALP: alkaline phosphatase enzyme activity; cathep: cathepsin enzyme activity; CL: cell length; NBC: mean number of digestive 'balls'/cell; tryp: trypsin enzyme activity; tryp.cathep and ALP.ACP: enzyme ratios. Results shown in this figure are mean values of all results obtained in this study for juveniles' weight, survival, enzyme activities, enzyme ratios and histological features. Enzyme activities, enzyme ratios and histological features were centered-reduced for comparison. 
Supplementary material in Journal of Comparative Physiology B for

"Digestive enzyme ratios are good indicators of hatchling yolk reserve and digestive gland maturation in early life stages of cuttlefish Sepia officinalis L.: application of these new tools in ecology and aquaculture"

Safi G. ${ }^{* 12}$, Martinez A.S. ${ }^{12}$, Le Pabic C. ${ }^{12}$, Le Bihan E. ${ }^{3}$, Robin, J.P. ${ }^{12}$, Koueta N. ${ }^{12}$

${ }^{1}$ Normandie Université, Université de Caen Normandie, UMR BOREA (Biology of Aquatic Organisms and Ecosystems, MNHN, UPMC, UCBN, CNRS-7208, IRD-207, UCN, UA), CS 14032, 14032 Caen cedex 05,

France

${ }^{2}$ Centre de Recherches en Environnement Côtier, Université de Caen Normandie, 54 rue du Docteur Charcot, 14530 Luc-sur-Mer, France

${ }^{3}$ Société IVAMER, 32 rue Fragonard, 14220 Thury Harcourt, France

*Corresponding author: Georges Safi: safigeorges@ hotmail.fr

Table S1 Number of samples (N) used to describe biological responses (i.e. weigh, enzyme activities and histological features) of juvenile cuttlefish Sepia officinalis during their early days after hatching in 2010 and 2011. Cuttlefish hatched from eggs collected from different spawning locations in the English Channel, namely BS: Bay of Seine, AC: Agon Coutainville, TB: Torbay, SE: Selsey.

\begin{tabular}{|c|c|c|c|c|c|c|c|c|}
\hline \multirow{2}{*}{$\begin{array}{l}\text { Biological responses } \\
\text { (N) }\end{array}$} & \multirow{2}{*}{ year } & \multirow{2}{*}{ site } & \multicolumn{6}{|c|}{ Age (days) } \\
\hline & & & 0 & 7 & 14 & 21 & 28 & 35 \\
\hline \multirow{8}{*}{$\begin{array}{l}\frac{+}{\frac{5}{00}} \\
\frac{.00}{00} \\
3\end{array}$} & \multirow{4}{*}{2010} & BS & 24 & 21 & 19 & 24 & 23 & 30 \\
\hline & & $A C$ & 24 & 21 & 21 & 23 & 20 & 28 \\
\hline & & $\mathrm{TB}$ & 24 & 22 & 20 & 22 & 23 & 29 \\
\hline & & SE & 24 & 15 & 13 & 18 & 23 & 30 \\
\hline & \multirow{4}{*}{2011} & BS & 24 & 21 & 21 & 20 & 23 & 24 \\
\hline & & $A C$ & 24 & 23 & 22 & 20 & 22 & 30 \\
\hline & & $\mathrm{TB}$ & 24 & 21 & 9 & 14 & 10 & 13 \\
\hline & & SE & 24 & 23 & 23 & 15 & 18 & 25 \\
\hline \multirow{8}{*}{ 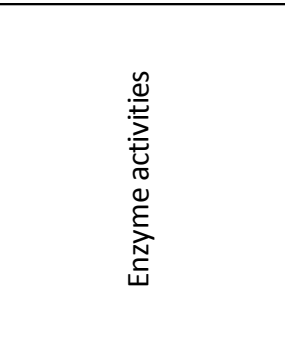 } & \multirow{4}{*}{2010} & BS & 5 & 5 & 5 & 5 & 5 & 5 \\
\hline & & $A C$ & 5 & 5 & 5 & 5 & 5 & 5 \\
\hline & & $\mathrm{TB}$ & 5 & 5 & 5 & 5 & 5 & 5 \\
\hline & & SE & 5 & 5 & 5 & 5 & 5 & 5 \\
\hline & \multirow{4}{*}{2011} & $\mathrm{BS}$ & 5 & 5 & 5 & 5 & 5 & 5 \\
\hline & & $A C$ & 5 & 5 & 5 & 5 & 5 & 5 \\
\hline & & $\mathrm{TB}$ & 5 & 5 & 5 & 5 & 5 & 5 \\
\hline & & SE & 5 & 5 & 5 & 5 & 5 & 5 \\
\hline \multirow{8}{*}{ 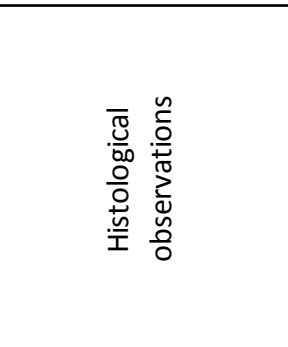 } & \multirow{4}{*}{2010} & BS & 6 & 6 & 6 & 6 & 6 & 6 \\
\hline & & $A C$ & 6 & 6 & 6 & 6 & 6 & 6 \\
\hline & & $\mathrm{TB}$ & 6 & 6 & 4 & 6 & 5 & 6 \\
\hline & & SE & 6 & 6 & 6 & 6 & 6 & 6 \\
\hline & \multirow{4}{*}{2011} & $\mathrm{BS}$ & 10 & - & - & - & - & - \\
\hline & & $A C$ & 10 & - & - & - & - & - \\
\hline & & $\mathrm{TB}$ & 10 & - & - & - & - & - \\
\hline & & SE & 10 & - & - & - & - & - \\
\hline
\end{tabular}



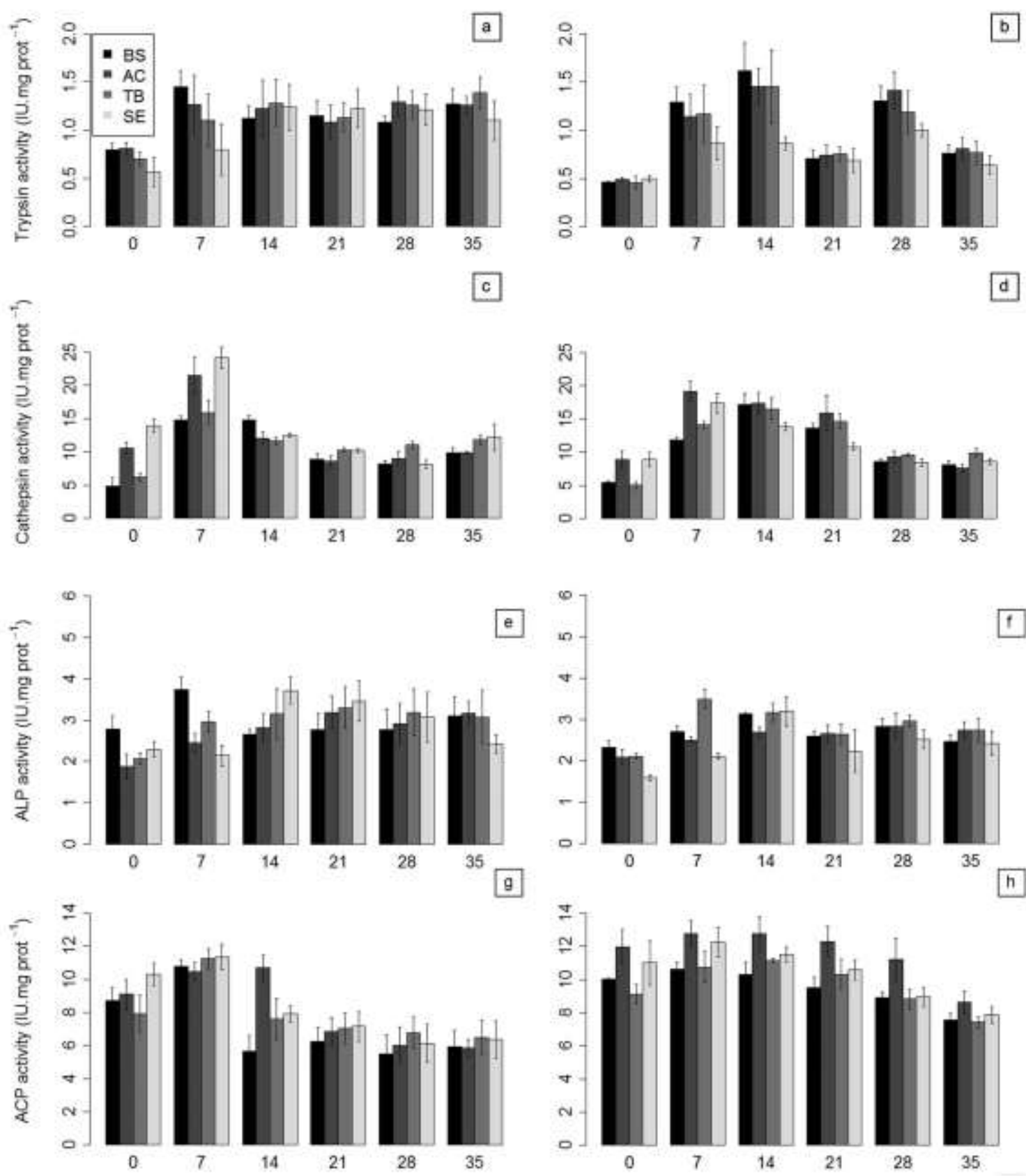

Days after hatching

894 Fig. S1 Trypsin, cathepsin, alkaline and acid phosphatases (respectively ALP and ACP) enzymes' activity in Sepia 895 officinalis juveniles during their early days after hatching (DAH) in 2010 (Barplots a, c, e and g) and 2011 (Barplots b, d, $\mathrm{f}$ and $\mathrm{h}$ ). $\mathrm{N}=5$ juveniles/site/DAH/year, values: mean \pm standard error. Cuttlefish hatched from eggs collected from different spawning locations in the English Channel, namely BS: Bay of Seine, AC: Agon Coutainville, TB: Torbay, SE: Selsey. 
Table S2 Statistical results of a two-ways ANOVA (factors site and age) applied for enzymatic activities (i.e. trypsin,

901 cathepsin, alkaline and acid phosphatases) in Sepia officinalis during their early days after hatching. Enzyme activities

902 barplots are presented in Fig. S1. N=5 juveniles/site/DAH/year. Cuttlefish hatched from eggs collected from different spawning locations in the English Channel, namely BS: Bay of Seine, AC: Agon Coutainville, TB: Torbay, SE: Selsey.

\begin{tabular}{|c|c|c|c|c|c|c|c|c|}
\hline \multirow{2}{*}{ Enzyme ratio } & \multirow{2}{*}{ year } & \multirow{2}{*}{ site } & \multicolumn{6}{|c|}{ Age (days) } \\
\hline & & & 0 & 7 & 14 & 21 & 28 & 35 \\
\hline \multirow{8}{*}{ 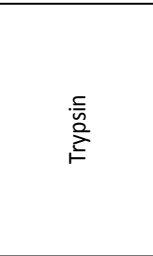 } & \multirow{4}{*}{2010} & BS & $a$ & a & $a$ & $a$ & $a$ & $a$ \\
\hline & & $A C$ & a & a & a & a & a & a \\
\hline & & TB & a & a & a & a & a & a \\
\hline & & SE & $\mathrm{a}$ & $\mathrm{a}$ & $\mathrm{a}$ & $\mathrm{a}$ & $\mathrm{a}$ & a \\
\hline & \multirow{4}{*}{2011} & BS & $\mathrm{b}$ & $a b$ & $a$ & $a b$ & $a b$ & $a b$ \\
\hline & & $A C$ & $a b$ & $a b$ & $a b$ & $a b$ & $a b$ & $a b$ \\
\hline & & TB & $\mathrm{b}$ & $a b$ & $a b$ & $a b$ & $a b$ & $a b$ \\
\hline & & SE & $a b$ & $a b$ & $a b$ & $a b$ & $a b$ & $a b$ \\
\hline \multirow{8}{*}{ 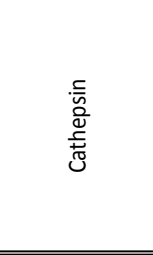 } & \multirow{4}{*}{2010} & BS & d d & abcd & abcd & cd & cd & cd \\
\hline & & $A C$ & $\mathrm{~cd}$ & $a b$ & bcd & $\mathrm{cd}$ & $\mathrm{cd}$ & $\mathrm{cd}$ \\
\hline & & TB & $\mathrm{cd}$ & $a b c$ & bcd & $\mathrm{cd}$ & $\mathrm{cd}$ & bcd \\
\hline & & SE & abcd & $\mathrm{a}$ & $\mathrm{bcd}$ & $\mathrm{cd}$ & $\mathrm{cd}$ & bcd \\
\hline & \multirow{4}{*}{2011} & BS & $\mathrm{cd}$ & abcd & $a b$ & abcd & bcd & bcd \\
\hline & & $A C$ & abcd & $a$ & $a b$ & $a b c$ & abcd & bcd \\
\hline & & TB & $\mathrm{d}$ & abcd & $a b$ & abcd & abcd & abcd \\
\hline & & SE & abcd & $\mathrm{ab}$ & abcd & abcd & bcd & $\mathrm{bcd}$ \\
\hline \multirow{8}{*}{ 高 } & \multirow{4}{*}{2010} & "BS & 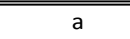 & 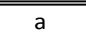 & 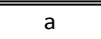 & 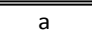 & 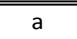 & 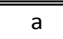 \\
\hline & & $A C$ & a & a & a & a & a & a \\
\hline & & TB & a & a & a & a & a & a \\
\hline & & SE & $\mathrm{a}$ & a & $\mathrm{a}$ & $\mathrm{a}$ & a & a \\
\hline & \multirow{4}{*}{2011} & BS & $a b c$ & $a b c$ & $a b$ & & $a b c$ & $a b c$ \\
\hline & & $A C$ & $\mathrm{bc}$ & $a b c$ & $a b c$ & $a b c$ & $a b c$ & $a b c$ \\
\hline & & TB & $b c$ & $a$ & $a b$ & $a b c$ & $a b$ & $a b c$ \\
\hline & & SE & $\mathrm{bc}$ & $\mathrm{bc}$ & $a b$ & $a b c$ & $a b c$ & $a b c$ \\
\hline \multirow{8}{*}{ ¿্ৰ } & \multirow{4}{*}{2010} & BS & abcd & abc & cd & abcd & cd & cd \\
\hline & & $A C$ & abcd & abcd & $a b c$ & abcd & $\mathrm{cd}$ & $\mathrm{cd}$ \\
\hline & & TB & abcd & $a b$ & abcd & abcd & abcd & $a b c d$ \\
\hline & & SE & abcd & $\mathrm{a}$ & abcd & abcd & bcd & $\mathrm{abcd}$ \\
\hline & \multirow{4}{*}{2011} & BS & abcdefg & abcdef & abcdefg & cdefgh & gh & gh \\
\hline & & $A C$ & abcd & $\mathrm{a}$ & $a b$ & abcde & efgh & gh \\
\hline & & TB & bcdefgh & abcde & abcde & defgh & gh & gh \\
\hline & & SE & abcdef & $a b c$ & abcde & cdefgh & fgh & $\mathrm{h}$ \\
\hline
\end{tabular}

Table S3 Spearman rank correlation test applied to investigate relationships between enzyme activities (i.e. trypsin, cathepsin, alkalin "ALP” and acid "ACP” phosphatases), enzyme ratios (i.e. trypsin/cathepsin and ALP/ACP) and histological observations (Digestive Gland Development “DGD” and Internal Yolk Surface "IYS”) at hatching day (i.e. 0 day after hatching) in Sepia officinalis $(\mathrm{N}=8)$. Correlation coefficients are above the diagonal and pvalues below. Significant correlations (pvalue $<0.05$ ) and their corresponding correlation coefficient are in bold.

\begin{tabular}{|c|c|c|c|c|c|c|c|c|c|}
\hline & & Trypsin & Cathepsin & Tryp.cathep & ACP & ALP & ALP.ACP & DGD & IYS \\
\hline & & \multicolumn{8}{|c|}{ Correlation coefficient } \\
\hline Trypsin & & - & 0.29 & 0.14 & -0.52 & -0.17 & 0.14 & 0.17 & -0.05 \\
\hline Cathepsin & & 0.493 & - & -0.86 & 0.43 & -0.55 & -0.71 & -0.81 & 0.86 \\
\hline Tryp.cathep & & 0.736 & 0.007 & - & -0.81 & 0.38 & 0.86 & 0.98 & -0.95 \\
\hline $\mathrm{ACP}$ & 岂 & 0.183 & 0.289 & 0.015 & - & -0.17 & -0.81 & -0.83 & 0.76 \\
\hline ALP & 熟 & 0.693 & 0.160 & 0.352 & 0.693 & - & 0.64 & 0.50 & -0.55 \\
\hline ALP.ACP & & 0.736 & 0.047 & 0.007 & 0.015 & 0.086 & - & 0.93 & -0.90 \\
\hline DGD & & 0.693 & 0.015 & 0.000 & 0.010 & 0.207 & 0.001 & - & -0.98 \\
\hline IYS & & 0.911 & 0.007 & 0.000 & 0.028 & 0.160 & 0.002 & 0.000 & - \\
\hline
\end{tabular}

911 Table S4 Spearman rank correlation test applied to investigate the relationships between weight, age, survival, enzyme

912 activities (i.e. trypsin, cathepsin, alkalin "ALP" and acid "ACP" phosphatases), enzyme ratios (i.e. trypsin/cathepsin and 
913 ALP/ACP) and histological features (mean Number of Balls/Cell "NBC" and Cell Length "CL") during early days after

914 hatching "DAH" (i.e. 0 - 35 DAH) of juvenile cuttlefish Sepia officinalis $(\mathrm{N}=24$ for NBC and CL; N= 48 for the rest of

915 the variables). Correlation coefficients are above the diagonal and pvalues below. Significant correlations (pvalue $<$

$9160.05)$ and their corresponding correlation coefficient are in bold.

\begin{tabular}{|c|c|c|c|c|c|c|c|c|c|c|c|c|}
\hline & & Weight & ALP & ACP & ALP.ACP & Trypsin & Cathepsin & Tryp.cathep & NBC & CL & Survival & Age \\
\hline & & \multicolumn{11}{|c|}{ Correlation coefficient } \\
\hline Weight & & - & 0.37 & -0.80 & 0.80 & 0.25 & -0.32 & 0.55 & 0.91 & 0.79 & 0.08 & 0.96 \\
\hline ALP & & 0.010 & - & -0.25 & 0.63 & 0.68 & 0.12 & 0.49 & 0.49 & 0.45 & 0.19 & 0.34 \\
\hline ACP & & 0.000 & 0.082 & - & -0.89 & -0.12 & 0.54 & -0.66 & -0.73 & -0.77 & -0.02 & -0.72 \\
\hline ALP.ACP & & 0.000 & 0.000 & 0.000 & - & 0.41 & -0.32 & 0.72 & 0.78 & 0.82 & 0.13 & 0.73 \\
\hline Trypsin & $\underline{g}$ & 0.089 & 0.000 & 0.398 & 0.003 & - & 0.34 & 0.50 & 0.48 & 0.38 & 0.22 & 0.27 \\
\hline Cathepsin & $\frac{\mathrm{E}}{\mathrm{E}}$ & 0.024 & 0.421 & 0.000 & 0.025 & 0.019 & - & -0.58 & -0.26 & -0.34 & 0.02 & -0.23 \\
\hline Tryp.cathep & $\mathrm{z}$ & 0.000 & 0.000 & 0.000 & 0.000 & 0.000 & 0.000 & - & 0.54 & 0.63 & 0.24 & 0.47 \\
\hline NBC & & 0.000 & 0.016 & 0.000 & 0.000 & 0.018 & 0.219 & 0.007 & - & 0.75 & 0.38 & 0.93 \\
\hline CL & & 0.000 & 0.027 & 0.000 & 0.000 & 0.071 & 0.104 & 0.001 & 0.000 & - & 0.18 & 0.82 \\
\hline Survival & & 0.632 & 0.234 & 0.909 & 0.419 & 0.177 & 0.881 & 0.140 & 0.098 & 0.447 & - & 0.00 \\
\hline Age & & 0.000 & 0.019 & 0.000 & 0.000 & 0.064 & 0.110 & 0.001 & 0.000 & 0.000 & 0.981 & - \\
\hline
\end{tabular}

